\title{
DIE PRÄSENTISCHEN TEMPORA BEI CHAUCER.
}

\author{
Als text sind zu grunde gelegt: I. für Chaucer's werke \\ folgende ausgaben:
}

1. The Poetical Works of Geoffrey Chaucer in six volumes edited by Richard Morris, L.L.D. with memoir by Sir Harris Nicolas. In the Aldine Edition of the British Poets, London 1886. (Unsere citate beziehen sich auf diese ausgabe, wo nicht ausdriicklich eine andere genannt ist.)

2. A Six-Text Print of Chaucer's Canterbury Tales in Parallel Columns from the following mss.: 1) The Ellesmere (in unserer abhandlung mit der abkürzung $\mathrm{E}$ bezeichnet). 2) The Hengwrt $154(=\mathrm{H})$. 3) The Cambridge Univ. Library Gg $4.27(=\mathrm{C})$. 4) The Corpus Christi College Oxford (= Corpus). 5) The Petworth $(=P)$. 6) The Lansdowne (=L).

3. Die Chaucer-edition von Gilmans: da zur vergleichung herangezogen, wo eine ausgabe von hss., wie die Six-Text-ed. nicht vorlag.

4. Fiir das Astrolabe: die ed. von Skeat in der Early English Text Society.

5. Für den Boethius: die ed. von Morris in der Early English Text Society.

II. Bei vergleichung der originale und quellen von Chaucer's werken sind benutzt folgende ausgaben:

1. Zur Tale of Melibeus: Albertani Brixiensis Liber Consolationis et Consilii ed. Thor Sundby Pro Societate Chauceriana London 1873.

2. Zum Boethius: die Editio Teubneriana.

3. Zum Romaunt of the Rose: die ausgaben des Roman de la Rose 1) von Méon, 4 bde. Paris 1814. 2) Die ausgabe des 1. teils Li Romanz de la Rose, première partie par Guillaume de Lorris vom oberlehrer Dr. Püschel im jahresbericht vom Friedrichs-gymnasium, Berlin 1872. 3) Le Roman de la Rose par Guillaume de Lorris et Jean de Meun dit Clopinel ed. Amsterdam 1735 (bezeichnet mit 0. A.).

Citiert ist uberall, wo nicht ausdrticklich eine andere quelle angegeben ist, nach der ausgabe von Morris und zwar gewöhnlich nach der verszahl, nur in der Tale of Melibeus und in 
der Persones Tale nach der seitenzahl mit beifugung der zeilenzahl der betreffenden seite. Die abktirzungen sind derartig, dass es zu ihrer erklärung keiner bemerkung bedarf.

\section{Einleitung.}

Wenn wir in der art der behandlung unseres stoffes von lisherigen arbeiten dieser art abweichen, so geschah dies, weil es uns schien, dass bei ibernahme der behandlungsweise aus einer der uns bekannten abhandlungen über tempora ein befriedigender einblick in den gebrauch der präsentischen tempora bei Chaucer nicht gewonnen werden könne. Wir sind in unserer abhandlung nicht von dem grundsatze ausgegangen, eine methodische einteilung mit rilcksichtsloser konsequenz iiberall durchzufuhren, sondern wir haben es für wesentlicher erachtet, uns je den speziellen bedurfnissen anzupassen, die aus der art des einzelstoffes erwachsen. So finden sich $z . b$. wol paragraphen tuber begrenzung der zeitsphäre beim praesens und beim perfectum, nicht aber beim futurum.

Was unsere unterscheidung der tempora in echte und stellvertretende beziglich relative betrifft, so ist dazu noch folgendes thber das wesen der tempora im allgemeinen zu erwähnen:

Das tempus bestimmt die zeitsphäre, in welcher ein verbalhegriff verwirklicht gedacht wird. Wir haben demgemäss in jedem tempus das produkt zweier begriffsfaktoren $\mathrm{zu}$ sehen und zwar sind diese 1) der wortbegriff oder der verbale faktor, 2) der zeitbegriff oder der temporale faktor. Bei den verben, die cine tätigkeit bezeichnen, kommt dazu noch der begriff des tätigkeitsträgers, der jedoch in bezug auf das tempus von untergeordneter bedentung ist.

Obige zwei begriffe sind nicht in allen temporibus gleich stark betont. Es liisst sich sogar, sobald die im tempus liegende zeitbestimmung durch andere nittel schon hinlänglich deutlich ist, eine vernachlässigung des zeitbegriffs in gewissen temporibus beobachten, welche so weit geht, dass eine zeitform für eine ganz andere zeitsphäre angewendet werden kann, als fur die im tempus bestimmte. Diese erscheinung findet sich jedoch nur bei dem temporibus der praesentialreihe, für welche sich dementsprechend die einteilung in echte und stellvertretende beztiglich relative notwendig macht. 
Was die verschiedenen modi der einzelnen zeitformen betrifft, so ist zu bemerken, dass bei der feststellung des gebrauchs der tempora nur der indicativ als die anssageform der wirklich gedachten handlung in betracht kommt, da nur hier der zeitbegriff als solcher massgebend fur die verwendung der verschiedenen formen ist, während im conjunctiv der zeitbegriff gegenuber dem begriff der irrealität ganz in den hintergrund tritt. Vgl. auch Brinkmann II, s. 673, 5.

Die werke; von denen Chaucer's autorschaft nicht mit sicherheit feststeht, glaubten wir nicht unbeachtet lassen zu durfen, und so haben wir da, wo es sich um bemerkenswerte erscheinungen handelte, stets auch das verhalten dieser werke zu den betreffenden erscheinungen geprift. Den Romaunt of the Rose haben wir in einem anhange einer besonderen betrachtung in stetem vergleich zu seinem original unterzogen, um so festzustellen, wie weit der vom original abweichende sprachgebrauch des ubersetzers mit dem bei Chaucer festgestellten gebrauch der präsentischen tempora ubereinstimmt. Ebenso ist von den echten werken, zum Boethius durchweg, das lateinische original und zur Tale of Melibeus bei bemerkenswerten stellen die lateinische quelle Albertani Brixiensis Liber Consolationis et Consilii zur vergleichung herangezogen worden.

Wenn wir uns schliesslich bie und da darauf eingelassen haben, zu konstatierten erscheinungen eine erklärung zu versuchen, so mag uns da, wo uns hieraus ein vorwurf entstehen sollte, das wort Tobler's zur entschuldigung dienen: 'Und begreifen möchte doch mancher gerne, nicht stehen bleiben bei einem verzeichniss von unleugbaren einzelnen tatsachen, noch auch bei einem darausgezogenen beobachtungsfacit, wenn dasselbe dem verstande unnahbar bleibt'. Verm. Beitr. 37, s. 209.

\section{TEIL.}

\section{Das praesens.}

Grimm, Gr. IV, 140. - Mätzner, Gr. II, 73. - Koch $§ 42$.

'Das praesens bezeichnet eine tätigkeit, welche der zeit angehört, in welcher sie ausgesprochen wird.' M. a. a. 0 .

Das präsens ist von allen temporibus dasjenige, welches 
die temporale beziehung am wenigsten betont. Dieselbe wird vielmehr vom sprechenden meist als selbstverständlich vorausgesetzt und nur in ganz besonderen fällen als gesondertes moment gefuhlt.

\section{Kap. 1.}

\section{Das praesens als echtes tempus.}

\section{$\S 1$. Das temporale element im praesens.}

a) Das praesens trägt die zeitliche begrenzung des verbalbegriffs lediglich in sich selbst.

$\mathrm{T}$. Lawe 477. This constable was not lord of the place, Of which I speke....

T. Knight 35. This duk of whom I make mencioun.

'I. Reeve 160. Sche seyde 'Allas! your hors goth to the fen'. u. dgl. $\mathrm{m}$.

b) Das praesens wird in seiner zeitlichen begrenzung des verbalbegriffs durch eine dazutretende zeitbestimmung gestlutzt.

Prol. 720. But now is tyme....

T. Knight 425. Thou walkest now in Thebes at thi large

T. Lawe 478. And yit I holde my pees'.

Die funktion der zeitbestimmung kann eine ortsbestimmung tibernehmen.

T. Knight 961. At the request of the queen that kneleth here.

T. Clerk II, 166. And here I swere.

Troilus II, 1253. 'Nece, ise who comth here ryde.

Pr. Schipm. 12. 'I smel a loller in the wind' quod he.

T. Schipm. 149. He nis no more cosyn unto me, Than is this leef that hongeth on the tre.

T. Pardoner 206. What corps is that, that passeth her forthby. u.dgl.m.

c) Das praesens wird in seiner zeitlichen begrenzung des verhalbegriffes durch gegenuberstellung eines anderen tempus gestutzt.

a) Dies kann sein ein tempus der präsentischen reihe und zwar das perfectum.

T. Clerk III, 38. But I desire, as I have doon byfore

ib. I, 12. Thus in delyt he lyveth and hath don yore

T. Lawe 174. Housbondes ben al goode, and han be yore.

u. dgl. $\mathrm{m}$.

Das futurum.

T. Knight 28.5. . . . whom I love and serve, And evere schal unto myn herte sterve. 
T. Knight 325. Love if the liste; for I love and ay schal.

'T. Clerk III, 61. 'This wil is in myn hert and ay schal be.

u. so sehr oft.

$\beta$ ) ein tempus der präteritalreihe und zwar hier nur das praeteritum selbst.

'T. Knight 699. But ther as I was wont to hote Arcite Now hoote I Philostrate.

T. Clerk V, 30. I woot and wist alway.

T. Lawe 733. As strong as ever he was, he is right now.

u. so sehr oft.

\section{§ 2. Ueber die grenzbestimmung der zeitsphäre des praesens.}

1. 'Das praesens bezeichnet eine tätigkeit, welche der zeit angehört, in der sie ausgesprochen wird.' M. II, s. 73. Die nähere begrenzung dieser zeitsphäre ist dem subjektiven bedurfniss des redenden uberlassen, indem er dieselbe einerseits auf einen moment beschränken, andererseits auf zeitabschnitte beliebiger grösse ausdehnen kann, sobald er sie nur in gegensatz zu einem andern zeitabschnitt setzt und somit dem praesens eine bestimmt begrenzte zeitsphäre zuweist.

Die zeitsphäre der gegenwart wird

a) auf den moment der aussage beschränkt.

T. Pardoner 206. What corps is that, that passeth her forthby.

ib. 69. I say it now wepyng with pitous vois.

u. so oft; vgl. beispiele sub $\S 1$.

b) auf zeitabschnitte beliebiger grösse erweitert.

T. Pard. 199. These riottours thre, of which I you telle.

ib. 266.

ib. 732.

Thus walk I lyk a resteles caytif.

T. N. P. 4.

So how I vanysshe flessh and blood and skyn.

This wydowe, of which I telle yow my tale.

u. so oft. Das praesens bezeichnet hier die ganze zeit, welche die erzählung der geschichte in anspruch nimmt - also einen ganz beliebigen zeitabschnitt.

2. Dabei werden zumeist auch handlungen der unmittelbaren vergangenheit oder der unmittelbaren zukunft mit in die gegenwart gerechnet, indem der redende, der in lebhafter beziehung zu diesen handlungen steht, dieselbe in keiner weise als von seiner gegenwart getrennt empfindet.

a) Die nächste vergangenheit

T. Knight 267. 'Whether seistow in ernest or in pley?

T. Frere 254. Ne herest nought thon, what the carter saith. 
'T. Clerk IV, 21). For to myn eeris cometh the vois so smerte...

'T. Squyer 102. He sayde: The kyng of Araby and Inde

My liege lord, on this solempne day

Saluteth you as he best can or may

He sendeth you... By me... This stede of bras'...

'T. Melib. 149, 31-32. wher as ye sayn: quelle: dixisti.

Ebenso T. Miller 304; T. Frere 158, 329; T. Somp. 426; Pr. Ba. 337,348 u. s. w.

Anmerkung. Es ist aber ein unterschied zu machen, ob der redende die nächste vergangenheit an sich noch in seiner anschauung als im zusammenhang mit der gegenwart stehend filhlt, [wegen der kürze der zwischen seiner gegenwart und dieser eben verflossenen vergangenheit liegenden zeit] oder ob dieser zusammenhang der beiden zeitsphären, die der redende im übrigen als deutlich getrennt empfindet, nur durch eine beiden gleichmässig angehörige handlung hervorgerufen wird. Da man im letzteren falle für die eine handlung auch nur ein tempus zu setzen pflegt, so entsteht die frage, welches tempus - das praesens oder das perfectum, welche eigentlich beide nebeneinander stehen sollten - den vorrang vor dem andern haben soll. - Der Deutsche und der Franzose ziehen hier das praesens vor, der Englïnder das perfectum. Dies zeigt sich auch schon bei Chaucer. - Doch ist ein fall auszunehmen. Soll es nämlich besonders betont werden, dass eine an sich der vergangenheit angehörige handlung auftälliger weise noch bis in die gegenwart hineinreicht, - so steht stets das praesens.

T. N. Pr. 74 By God, me mette I was in such meschief

Right now, that yit myn hert is sore afright. u.ö.

Troilus V, 1351 But in two monethes yit ye not retourne.

Sonst steht bei Chaucer im obigen falle schon vorwiegend das perfectum; vgl. Perfectum s. 40. Jedoch findet sich auch das praesens; vgl. ib. s. 43.

b) Die nächste zukunft.

Dem redenden schwebt eine unmittelbar bevorstehende handlung so lebhaft vor, dass er sie schon als gegenwärtig empfindet.

'T'. Miller 5̌34. 'I come anon.'

ib. 537.

For after this I hope ther cometh more.

ib. 630. He thought, 'Allas, for now cometh Noes floud!'

T. Bathe 154. The nexte thing, that I require the, Thou shalt it doo.

Pr. Maunc. 104. 'wel, sir' quod he, 'now herkyn what I say.' und so oft.

3. Anders liegt der fall in folgenden beispielen, die nicht dadurch erklärt werden können, dass der redende die vergangene handlung $\mathrm{zu}$ seiner gegenwart rechnet, - sondern wo das praesens unverkennbar statt des perfects steht. 
T. Miller 580. Why ryse ye so rathe?

$=$ Warum seid ihr so frilh auf?

T. Lawe 807. Of which the name in my text nought I fynde.

Dasselbe T. Monk 265; Troilus IV, 1387 u. öfter.

Gerade dies verb steht fast regelmässig im praesens in diesem zusammenhange.

T. Bathe 6. This was the old oppynyoun as I rede;

Dasselbe T. Lawe 997; T. Nonne Pr. 290 u. öfter.

Anch dies verb findet sich ziemlich ziemlich häufig so.

Troilus II, 653. Lo! this is he.

Which that myn uncle swerth he moot be dede.

ib. V, 1282. Paraunter ther thow dremest of this boor, It may so be that it may signifye .... .

Lucrecia 45. And axeth hem 'what tydynges heren ye

Adriane 203. That I ne repente not to yeve yow lyfe

Phyllis 157. But syn thus synfully ye me begile,...

u. andere mehr.

Das ne. I forgel haben wir bei Chaucer nicht nachweisen können.

Dieser gebrauch des praesens ist als folge einer starken kturzung von ausdrucken anzusehen, deren umfangreiche grammatische form ihrem klaren und einfachen gedankeninhalte gegentuber als zu umständlich empfunden wurde. - So sagte man statt: Es ist mir bekannt, denn ich habe gelesen, gehört, geseben, erfahren etc. - ich lese, ich höre, ich sehe, ich erfahre und ähnlich in den ubrigen fällen. - Diese ausdrucksweise ist zwar grammatisch auffällig, aber beztiglich ihres inhaltes so absolut klar, dass ein missverständniss gar nicht möglich. -

Anmerkung. Hieran reiht M. den gebrauch des praes. bei quellenangaben von citaten.

T. Miller 343. For thus seith Salomon.

T. Clerk VI, 216. As saith seint Jame, if ye his pistril rede.

Ebenso Pr. Bathe 49, 51, 64, 91, 182, 325, 652; T. Bathe 269, 309, 336; T. Somp. 314; Pr. Lawe 25, 76, 7i; T. Lawe 309; T. March 881, 998-1007 u. sehr oft.

M. scheint jedoch übersehen zu haben, dass es sich hier um eine rein bildliche ausdrucksweise handelt, indem der autor statt seines werkes gesetzt wird und 'sagen' sowie ähnliche ausdrücke die bedeutung haben: 'es steht geschrieben in', 'es wird gesagt in' u. s. w.

An die frage, wann dies bezw. das betreffende buch geschrieben worden ist, wird hierbei gar nicht gedacht. Es handelt sich nur darum, zu konstatieren, dass eine gewisse meinung, die der schriftsteller ansspricht, anch durch biicherstellen gestiitzt wird, 
Diese redeweise ist also eine bildliche und ihr inhalt gehort nicht der vergangenheit, sondern der gegenwart an. Wenn es liberhaupt nötig ist, einen beweis hierfiir anzufiihren, so mögen die folgenden stellen als solcher angesehen werden.

T. Knight 340. .... as olde bookes sayn, ....

T. Bathe 126. Redith $0 \nabla y d$, and ther ye mow it leere.

'T. March 1040. The Romayn gestes eek make remembraunce

T. Melib. 15i,24. for the book saith: quelle s. 52,14: Scriptum est enim.

ib. 166, 11. for the book saith: quelle s. 2, 1: scriptum est namque u. so oft.

T. Monk 127 as saith the Prophe.

Ebenso T. Bathe 312; T. Monk 470, 508; T. N. Pr. 443, 509 u.s. w. Ganz originelle beispiele sind:

Pr. Lawe 93. Metamorphoseos wot what I mene.

T. N. Pr. 539. as saith us (Eneydos).

S. T. 4549, ebenso E. H. C. zeigen seith; Corpus, P. L., seyde. T. Monk 665: as saith Machabe, ebenso alle hss. der S. T. 3845.

Hertzberg, Uebers. der C. T. in der anm. s. 614, bemerkt dazu sehr treffend: 'Was die nameusform Metamorphoseos betrifft, so glaube ich .. ... nicht, dass Chaucer sich darunter einen menschen vorgestellt habe' (er spricht öfters von biichern in der bekannten figur wie von personen). Wir haben also hier durchaus kein praes. vor uns, dass an stelle eines praet. oder perf. steht, sondern ein gewöhnliches praes., dass seiner natur nach unter kap. 3 gehört; vgl. kap. 3, 4.

Allerdings kann bei anführung von aussprüchen berühmter personen auch das praet. stehen. Dann aber ist es klar, dass dieselben auch wirklich als personen gefublt werden und es handelt sich nicht um eine bildliche redeweise.

Pr. Coke 6. Wel seyde Salomon in his language.

Ebenso T. Bathe 96-97; Pr. Bathe 12, 16, 64-65, 73, 108, 111; T. Miller 41-42 u. öfter. Auffällig ist jedoch, dass die beiden tempora unmittelbar nebeneinander stehen.

Pr. Bathe. Thapostil, when he spekth of maydenhede, He sayde.

T. Bathe 269. Wel can the wyse poet of Florence, 'That hatte Daunt, speke of this sentence.

u. öfter; vgl. kap. 3,4 .

Kap. 2.

Das praesens als stellvertretendes tempus.

Das praesens kann sich seiner temporalen eigentlumlichkeit so weit entkleiden, dass es die zeitsphäre der verwirklichung eines verbalbegriffs nur noch relativ fixiert, indem es nun nicht mehr die zeit jener verwirklichnng bestimmt, sondern nur deren dauer begrenzt. 
Dieser fall tritt ein, wenn das praesens andere tempora vertritt und zwar kann es eine derartige vertretung thernehmen 1) fur das praeteritum, 2) fur das futur.

\section{§1. Das praesens historicum.}

Handelt es sich darum, tiberraschend schnell eintretende oder in rascher folge einander drängende ereignisse entsprechend darzustellen, so kann, besonders wenn die zeitliche beziehung durch den zusammenhang schon hinreichend bestimmt ist, die zeitsphäre der handlung durch das tempus gänzlich ignoriert werden. Dies geschieht in der absicht, die ganze kraft der vorstellung auf den verbalbegriff $\mathrm{zu}$ konzentrieren und ihn von allen anderen nebenbegriffen, die in diesem falle nur hemmend auf die darstellung einwirken, zu befreien. Da nun das praesens von allen temporibus dasjenige ist, welches den verbalbegriff am wenigsten durch den zeitbegriff beschränkt, bezw. in unserem sinne abschwächt, so ist es das flir obige darstellungsweise am meisten geeignete tempus.

Das ideal für diese darstellungsweise wäre, wenn man die verbalbegriffe aller beziehung auf zeit und person entkleiden und so die reinen verbalbegriffe an einander reiben könnte. Dies haben denn auch einige sprachen im infinitivus historicus erreicht.

Derartige infinitive finden sich auch bei Chaucer', wenn man sie auch wegen ihres sehr vereinzelten vorkommens nicht mit dem namen historische infinitive belegt, sondern sie besser als infinitive des ausrufs auffasst. Ein wesentlicher unterschied zwischen diesen beiden arten des infinitivs existiert aber absolut nicht, denn beide verdanken ihre entstehung gleichmässig der lebhaftigkeit der darstellung. Der infinitiv steht in den vier zu belegenden fällen, um teils die aussergewöhnlich rasche, teils die ausserordentlich beftige art der ausfuhrung der betr. handlung zu bezeichnen - und zwar steht der infinitiv mit und ohne $t o$.

Troilus II, 1107. 'By God' quod he, 'I hope alway byhynde!' And she to laugh, it thoughte hire herte breste.

Ebenso E. ed. G. II, ib. s. 467.

${ }^{1}$ Fiedler u. Sachs, b. II syntax s. 54, führen einige weitere beispiele für diesen infinitiv im Engl. an, von denen jedoch die aus Ch. citierten, wie auf den ersten blick erhellt, zu streichen sind. Aufrecht zu erhalten sind nur zwei der dort angefiihrten beispiele, nämlich das erste und dritte. 
'Troil. II, 1731. '. . . . God hym amende!'

And inwarde thus ful softely bygynue:

'Nece, I conjure, and heighly you defende, ...

Fame II, 388 (am anfang eines absatzes).

And I adoun to loken thoo,

And behelde feldes and playnes,... .

Die stelle ist jedoch unsicher, denn E. ed. G. III, s. 33 zeigt:

And I adoun gan loken thoo

And behelde feldes and playnes...

Welche lesart die richtige ist, konnten wir, wie auch bei folgendem beispiel, nicht entscheiden, da uns keine handschriften zu gebote standen. Ferner ein beispiel aus dem unsicheren Ch. Dream 1653.

For when the time ye set was past,

The queene to counsaile sone in hast

What was to doe, and said(,) great blame

Your acquaintaunce cause would ... .

Auch hier weicht E. ed. G. III, s. 632 ab:

For when the Time ye set was past,

The queene to o $k$ counsaile sone in hast,

What was to doe.

Es ist noch ein höherer grad von lebhaftigkeit in dieser richtung hin möglich, indem das verbum ganz ausgelassen wird. Der satz nimmt dann vollständig das gepräge eines ausrufs an.

Troil. I, 1072. But Troylus lay tho no lenger doun,

But up anone upon his steede bay,

And in the feelde, he pleyde the leoune, ...

ib. II, 133. 'As helpe me God, I not nought what ye mene.

'And I youre borough, ne nevere shal, for me,

'This thynge be told to yow, as mote I thryve!'

ib. II, 786. . . . e ek men ben so untrewe,

That right anon, as cessed is hire leste,

So ceseth love, and forth to love a newe.

Anmerkung. Das Neuenglische kann eine ausserordentlich rasche aufeinanderfolge von handlungen dadurch wirksam darstellen, dass es alle nebenbeziehungen aus den verbalbegriffen ausscheidet und als prädikat setzt, während die verbalbegriffe als infinitive das subjekt bilden - ein gebranch, der sich bei Chancer noch nicht findet.

To rush forward - to shatter the door - to seize Jone in his arms - to hurry from the mansion - seemed to him the work of an instant! - Bulwer, The Last Days of Pompeii V, 5 (Tauchnitzed. s. 411, z. 1i-19).

Das psychologische moment, welehes M. II, s. 74 als erklärung des praesens historicum anfuhrt, erklärt nur dasjenige praes. hist., welches nicht die handlungen in rascher aufein- 
anderfolge bezw. in energischer bewegung darstellt, sondern, 'mit interesse bei der beschreibung von scenen verweilend', eine pause in der erzählung eintreten lässt, nm so das bild in seiner vollen kraft einen moment lang ungestört wirken zu lassen. Es bedeutet also einen ruhepunkt in der erzählung und ist von dem obenerwähnten praes. hist. wol zu unterscheiden. Dass in der tat ein sehr wesentlicher unterschied zwischen diesen beiden arten des praes. hist. besteht, zeigt die tatsache, dass das Mhd., welches nur die letztere art kennt; vgl. Grimm, Gram. IV, 142 ff.

Wir behandeln desshalb beide arten getrennt, und zwar:

A. Das praes. hist. im fortschritt der erzählung.

B. Das praes. hist. im stillstand der erzählıng.

Anmerkung. Wenn wir das praes. hist. im folgenden ausführlicher behandeln, als es das grammatische interesse dieses tempus zu erfordern scheint, so geschieht dies aus zwei gründen. Einmal, weil es nötig ist, um einen überblick über das allmählige vordringen des praes. hist. im Me. zu erlangen, die ausdehnung des gebrauchs desselben bei einzelnen schriftstellern, die als grosse etappen gelten können, genau festzustellen zweitens aber, weil es einen wesentlichen einblick in die eigenart der darstellungsweise gibt, zu beobachten, in welcher weise ein dichter nicht nur im grossen und ganzen, sondern gerade im einzelnen derartige darstellungsmittel, wie das praes. hist., verwendet.

\section{A. Das praes. hist. im fortschritt der erzählung.} Gust. Rudolph s. 261.

1. Das praes. hist. bezeichnet einfach den fortschritt der bandlung.

a) Es bezeichnet gegenuber dem praeteritum den wichtigeren fortschritt der handlung.

T. Knight 610. By helpyng of a frend brak his prisoun,

T. Lawe 1005.

And fleeth the cite fast as he may go.

And whan sche saugh hir fader in the streete,

Sche light adoun and falleth bim to feete.

T. Clerk III, 129.

He tolde poynt for poynt, in schort and playn,

And him presentith with his doughter deere.

Ebenso T. Lawe 778-780; T. Knight 1783; T. Schipman 299; Tesbe 179-181 u. öfter.

b) Es bezeichnet bisweilen den fortschritt der handlung gegenuber dem praeteritum, welches dann das tempus der nebenumstände ist. 
T. Miller 508. He rometh to the carpenteres hous, And stille he stant under the schot wyndowe;

Unto his brest it raught, it was so lowe;

'T. Knight 1359.

And softe he cowhith with a semysoun.

And in hire hour he walketh forth a paas

Unto the lystes, ther hir temple was.

T. Lawe 505. Sone after comth this constable hom agayn,

And eek Alla, that was kyng of that lond.

Ebenso T. Squyer I, 288 u. öfter.

c) Nicht selten jedoch steht es im wechsel mit dem praeteritum, ohne dass ein anderer grund fur seine anwendung zu erkennen wäre als die absicht, abwechslung in die erzablung zu bringen.

T. Reeve 147. This meller goth agayn, and no word seyde,

But doth his note, and with the clerkes pleyde

Phil. 7i-80. . . . and y af him yeftes grete,

And him conveyth thurgh the maistir strete

of Athenes, and to the see him broghte

And turneth home; no malyce he ne thoghte.

Ebenso T. Knight 2098-2104 u. so oft.

Dicse angefthiten stellen sind besonders interessant, weil das praes. hist. und das praeteritum hier ganz regelmässig mit einander wechseln.

Auffallend sind die beispiele; wo praes. hist. und praeteritum ohne jeden erkennbaren grund unmittelbar neben einander stehen.

T. Lawe 246. They sworen and assenten every man

To lyfe with hir and dye

ib. 322. But al to deere they bought it ar they ryse.

T.Clerk I, 120. With hertly wil thay sworen and assentyn

Lucrecia 125 . She axeth grace, and seyde al that she kan.

Es scheint uns nach analogie der thrigen stellen (vgl. auch weiter unten die stellen Troilus I, 473 sub B I, 5. d) nicht nötig, in den beiden letzten beispielen assenten als synkopiertes praeteritum aufzufassen. Vgl. ten Brink, Chaucer's Sprache $\mathbf{u}$. Verskunst, Leipzig 1884, § 194.

In den meisten fällen scheint hier der reim einen starken einfluss getibt zu haben.

2. Das praes. hist. dient dazu, mit ubergehung aller nebenumstände nur die hauptmomente anzufuhren, und so verleiht es der darstellung etwas abgerissenes, stossweise vorruckendes, oder es bezeichnet nur das resultat einer handlungsreihe, mit 
ubergehung dieser selbst, und gibt gewissermassen nur eine kurze inhaltsangabe derselben.

a) Es bezeichnet nur die hauptmomente der handlung:

T. Miller 310. This carpenter goth forth, and comth agayn.

T. Clerk IV, 195.

His wyves fader in his court he kepith, Til that the soule out of his body crepith.

T. Bathe 216. And takith his wyf, and goth with hir to bedde.

Ebenso T. Frere 106-8; T. Clerk VI, 169-71; T. March 615-16; T. Squyer I, 164-65. II, 36-38, 165. II, 93-94; T. Pardoner 243-44; Troilus V, 186 u. öfter.

Ein besonders hervorzuhebender fall findet sich

T. Squyer I, 267.

This noble kyng is set upon his trone;

This straunge knight is fet to him ful sone.

wo die beiden praes. hist. durch den binnenreim ganz besonders hervorgehoben werden.

b) Es gibt nur das endergebniss einer kürzeren oder längeren handlungsreihe an, indem diese selbst ubergangen wird.

T. Lawe 276. What schuld $I$ in this tale lenger tary?

Sche rideth to the sowdan on a day,

ib. 867. . . but schortly this is thende, Hom-ward to Rome they schapen hem to wende.

ib. 1049. And dame Custaunce, fynally to say,

Ypermystre 114. Toward the toun of Rome goth hir way.

And shortly, leste this tale be to longe, This Lyno and she beth $i$-broght to bedde.

Ebenso T. Lawe 893; T. Schipman 313-314; Troilus IV, 117; Lucrecia 106; Ypsiphile 277; Adriane 285-88; Philom. 30-32 u. so oft.

Anmerkung. Dies praes. hist. zeigt grosse ähnlichkeit mit dem praesens der berichterstattung; vgl. weiter unten.

c) Hieran schliesst sich unmittelbar der gebrauch des praes. hist. im abschluss einer handlungsreihe. Das letzte verb, welches an sich noch einen fortschritt der handlung bezeichnet, steht im praes. hist. und schliesst so die betreffende handlungsreihe wirksam ab.

T. Bathe 62. And takith his leve, and wendith forth his weye.

T. Frank 291. And home they gon in joye and in solas.

T. Schipm. 322. And forth he rideth hom to his abbay ...

Ebenso T. Knight 170; T. Miller 434; T. Reeve 233, 240; T. Lawe 140, 1033, 1059-60; T. Bathe 131; T. Somp. 458; T. March 521, 
558-60 (mehrere verben im praes. hist.); T. Sqyuer II, 46; T. Frank 876; T. Pardoner 389, 416; T. Monk 638-40; T. Nonne Pr. 174; Troilus V, 1658; Dido 28; Adriane 57, 277; Ypsiphile $140-41,229-30$; Philomene 56; Phillis 88; Ypermystre 60 u. so sehr oft.

Unsichere werke: C. of Love 1431, 1435; Ch. Dream 786.

So findet es sich oft am ende einer strophe, eines abschnittes, oder selbst einer tale. T. Lawe 287, 301, 630, 672, 777; T. Bathe 216; 'T. Clerk I, 132-33, 138-40 (ende der tale), IV, 7; T. Frank 74, 85; Parl. of Foules 532; Troilus I, 1012. III, 1771 (ende der erzählung); Tesbe 181 u. öfter.

Diesem gebrauche entsprechend zeigt sich das praes. hist. hin und wider im temporalsatz mit til, wo es der handlung des hauptsatzes den abschluss gibt.

T. Schipman 297.

Thay drynke, and speke, and rome a while and playe,

Phillis $26-28$.

Til that dan Johen rydeth to his abbaye.

The see ... posseth hym up and doune

Til Neptunus hath of hym compassyoun, ... u. of fter.

3. Das praes. hist. steht zur einleitung und wirksamen ankündigung einer neuen handlungsreihe. Gewöhnlich steht dann nur ein praes. hist., selten zwei oder mehrere, zu beginn derselben, während die erzählung sich dann im praet. weiterspinnt. Dieser gebrauch des praes. hist. ist bei Chancer ausserordentlich beliebt.

a) Es leitet eine neue handlungsreihe ein,

a) ohne besondere merkmale.

T. Miller 260. Adoun he goth, and tolde his mayster soone ...

T. Reeve 96. This Aleyn maketh redy al his gere And on an hors the sak he cast anoon.

Ebenso T. Miller 169, T. Lawe 999; T. Frank 504; T. Doctour 153, 207; (Cb. Dream 1569); Ypsiphile 106 u. s. w.

Zwei praes. hist.:

T.Reeve 151. 'This Johan goth out, and fynt his hors away And gan to crye ... u. öfter.

B) Es steht entsprechend seiner funktion am anfang eines absatzes oder einer strophe: T. Lawe 309, 351, 407, 491 (zwei praes. hist.), 778, 813, 869, 876, 897, 904, 918; T. Clerk II, 65. III, 148; T. Frank 603; T. Sec. Nonne 218 (zwei praes. hist.); T. Monk 704; Troilus V, 1547, 1681 u. s. w. 
y) Besonders zu behandeln sind die verba dicendi zur einleitung der direkten rede. Diese stehen nach Bockhoff s. 16 und Rudolph s. 262 in den betreffenden altfranzösischen denkmälern besonders häufig im praesens historicum. Bei Chancer können wir dies nicht konstatieren; im gegenteil macht sich die neigung geltend, diese verba ins praet. zu setzen, selbst wenn sie unmittelbar auf ein praes. hist. folgen.

T. Miller 576. This Absolon knokketh al esily, And seyde: '. . .

T. Doct. 247. Sche riseth up, and to hir fader sayde: '. .

T. Monk 219. But Daniel expoundith it anoon, And sayde: '. . .

Ebenso 'T. Knight 361-65 (sechs praes. hist.), 1361-62, 1906; 'T. Miller 239; 'T. Reeve 151-52; T. Lawe 277-78, 351-52; 'T. March 583-84 u. öfter.

Desshalb ist das praes. hist. jedoch hier nicht ausgeschlossen - es finden sich sogar eine ganze anzahl von fällen mit demselben. Aber es ist dann meist durch anderweitige gritinde verursacht:

So durch die betonung der art und weise, in welcher eine handlung ausgeftuhrt wird.

T. Miller 511. And softe he cowhith with a semysoun: '. .

Ebenso T. Somp. 338; Adriane 325; Philomene 101.

T. March 1122. And sche answerith: '- um das schnelle, schlagfertige erfolgen der antwort zu bezeichnen.

T. March 893 steht es im consecutivsatz; vgl. unten.

Dido 385-90 wird die verzweiflungsvolle klage der Dido im praes. hist. geschildert und daran schliesst sich an: And seith: " - also durch die lebhaftigkeit der ganzen schilderung bewirkt.

Nur verhältnissmässig wenig stellen bleiben tubrig, in denen das praes. hist. auf grund seiner einleitenden funktion steht.

T. Knight 762. This Palamon answereth: '. . .

T. Lawe 284. The sawdan seith: '. . .

Lucrecia 44. And bad hir servauntes doon hir besynesse, And axeth hem: '. . u. andere.

Jedenfalls finden sich diese beispiele in ganz verschwindender minderzahl gegentuber denen, in welchen die direkte rede durch das praeteritum der verba dicendi eingeleitet wird.

Etwas anderes ist es bei der anfuhrung indirekter rede; wenn nämlich der inhalt der rede im praes. hist. gegeben wird, 
so steht meist auch das einleitende verburn dicendi im praes. historicum.

T. Lawe 523. But nevertheles ther was gret mornyng

Among the people, and seyn they can not gesse...

ib. 780. And asketh wher his wyf and his child ys.

T. Frank 2:4. He seith, he may not fro his deth asterte

Him semeth, he felith his herte colde.

Troil. V, 1430. But in hire letre made she swich feeste,

That wonder was, and swerth she loveth hym beste.

und so öfter.

Seltener findet sich das einleitende verb. dic. im praes. hist., wenn der inhalt der indirekten rede im praet. steht.

Lucrecia 154. Hir frendes axen what hir aylen myghte.

b) Entsprechend der sub a angeführten funktion wird es gern verwandt, um nach längerem stillstand der erzählung die abgebrochene handlung wider aufzunehmen.

$\alpha$ ) nach einer längeren reflexion: T. Lawe 218. Nachdem der verfasser sich in einer reflexion von drei strophen ergangen hat, setzt endlich die handlung wider ein mit:

To schippe is brought this woful faire mayde.

Ebenso ib. 407, 687, 848, 947, und zwar setzt es in diesen mit einer neuen strophe an, und so öfter.

$\beta)$ nach einer längeren rede oder wechselrede der helden.

T. Frere 238. And with that word thay riden forth her way.

Ebenso ib. 106; T. Somp. 94 (anfang eines absatzes und zwei praes. hist.); T. March 330; T. Squyer I, 161 u. öfter.

4. So eignet sich das praes. hist. auch ganz besonders dazu, die einem vorgange unmittelbar folgende handlung wirksam darzustellen. Dieser vorgang kann bestehen

a) in einer handlung.

T. Miller 623. Of goth the skyn an hande brede aboute.

Als unmittelbare folge der berührung mit dem gluhenden eisen.

Das praes. hist. steht besonders wirksam am anfang des verses. ib. 633. And doun he goth...

(sc. er hat soeben den strick durchgeschnitten, an dem er hing).

T.Cl.VI, 169. Waltier hir gladith, and hir sorwe slakith,

T.Squ. II, 36. Her maistres clepeth wommen a gret route And up they risen ... u. öfter.

b) In einem befehl, einer bitte, aufforderung.

T. Knight 2010. His officers with swifte foot they renne, And ryde anon at his comaundement.

in folge eines soeben erhaltenen befehls. Ebenso

T.March.71i. And sche obeieth be hir lief or loth. 
T. Pard. 506. Anon thay kisse and riden forth her waye.

In ausfuhrung der an sie ergangenen aufforderung - Ebenso T. Miller 248; T. Frank 752; T. Schipman 67; Ypermystre 111.

c) in einer rede, verktundigung, mitteilung ete, mag dieselbe in direkter oder indirekter rede stehen.

T. Knight 1703.

The voice of the poepul touchith heven ...

In folge der verktindigung des herolds. Ebenso ib. 1012-13 (direkte rede).

T. Miller 428. This seely carpenter bygynneth quake;

In folge der ihm soeben (von Nicolas) gemachten mitteilung.

T. Bathe 3i2. This knight avysith him, and sore sikith.

In folge der ihm soeben gestellten alternative (direkte rede).

T. Frank 846. 'No, no' quod he, and sorwfully he siketh.

In folge der eben durch seine antwort konstatierten tatsache.

Aehnliche fälle T. Frank 25 (indirekte rede), 801 (direkte rede); Adriane 238 (direkte rede) u. öfter.

d) in einer tiberlegung in gestalt eines selbstgespräches, in einem gefassten beschluss oder in einer versicherung.

T. Reeve 298. 'Allas!' quod sche, 'I had almost mysgoon;

I had almost goon to the clerkes bed,

Ey, benedicite! than had I foule i-sped!'

And forth sche goth, til sche the cradil fand.

Tesbe 150. 'If it so falle that my Piramus ...

Be comen hider, and may me nat fynde,

He may me holden fals, and ek unkynde.

And oute she comith, and after hym gan espien.

Troil.IV,918. Goth Pandarus, and Troilus he soughte.

In folge eines soeben gefassten beschlusses. Auch hier steht das praes. hist. sehr wirksam am versanfang und zugleich am anfang der strophe.

T. Frank 826. 'My trouthe wol I kepe, I wol noght lye.'

With herte soor he goth unto his cofre

And broughte gold unto this philosophre.

Zur bestätigung seiner versicherung.

5. Ganz besonders ist diese art des praes. hist. beliebt zur darstellung lebhafter bewegung, welch letztere äusserlich oder innerlich sein kann. Es sucht hier den eindruck der gleichzeitigkeit bei in der tat sich folgenden handlungen zu erwecken.

a) Die bewegung ist äusserlich, $d$. h. sie bezieht sich nur auf vorgänge körperlicher natur.

So bildet das praes. hist. ein treffliches darstellungsmittel

a) fur schnell auf einander drängende handluugen. 
T. Knight $1744-51$.

In $g$ oth the speres ful sadly in arrest

Ther seen men who can juste, and who can ryde;

In g oth the scharpe spore into the side.

Ther schyveren schaftes upon schuldres thykke;

He feeleth thurgh the herte-spon the prikke.

Up sprengen speeres on twenty foot on hight.

Out goon the swerdes as the silver bright.

The helmes thei to-hewen and to-schrede,...

Aehnlich T. Lawe 866; Cleopatra 56-60,61-70 u. öfter. Wie es bei dieser art des praes. hist. lediglich auf betonung der verbalbegriffe abgesehen ist, zeigt sich hier wie auch in später folgenden beispielen sehr deutlich daran, dass dieselben und zwar teils auf kunstliche weise (durch inversion) an die versanfänge gestellt sind.

及) um das unauf haltsame, unabwendbare, unerbittlich eintretende zu bezeichnen.

T. Knight $1885-88$.

Swelleth the brest of Arcyte, and the sore

Encresceth at his herte more and more

The clothred blood, for eny leche-craft

Corrumpith and...

Aehnlich T. Lawe 196; T. Clerk III, 89; Troilus V, 59, 1760-61; Philomene 103 u. öfter.

r) um den eindruck des emsigen, eifrigen, eiligen, hastigen, geschäftigen $\mathrm{zu}$ erhöhen.

'T. Miller 5ว9. Who rubbith now, who froteth now his lippes

With dust, with sand, with straw, with cloth, with clippes But Absolon?

'T. March 767. He kombith him, he pruneth him and pyketh

He doth al that unto his lady likith, ...

T. Schipman 302.

Now goth this marchaund faste and busily

About his neede, and bieth and creaunceth, ...

Ebenso T. Miller 575; T. March 12, 563, 711; T. Squyer II, 292, 296; T. Frank 96, 99, 520-22; 'T. Ch. Y. 311; T. Pardoner 376; T. N. Pr. 362-63; T. Maunc 52; Troilus V, 772 u. s. w.

d) um das plötzliche, unerwartete, iberraschende eines vorgangs hervorzuheben.

T. Kn. 1707. Up goth the trompes and the melodye.

ib. 1783. And by the force of twenti he is take ...

'T. March 765. Up ryseth Damyan the nexte morwe, All passed was his siknes and his sorwe.

Cleopatra 56. Up gooth the trumpe ... 
und so in allen den stellen, wo ein praes. hist. eine kampfoder lärmscene eröffnet; vgl. sub $\alpha$.

Ferner T. March 330; T. Pardoner 243; Cleopatra 75 u. ö.

$\varepsilon)$ um das längst mit spannung erwartete, durch andere handlungen schon vorbereitete eintreten eines ereignisses anzuktindigen.

Adriane 141. The gayler cometh, and with hym Theseus.

ib. 300. Ryght in the dawenynge awaketh shee,

(Ch. Dream 1149.

And gropeth in the bed, and fonde ryght noght.

Forth goeth the ship, outgoeth the sonde.)

Ebenso T. Reeve 98; Ch. Dream 1569 u. öfter.

5) um das sofortige, präzise eintreten eines ereignisses zu bezeichnen. - Hierher kann man 'zunächst alle sub 4 angefuhrten stellen zählen, ebenso die mehrzahl derjenigen sub 3 a ad $\alpha$ ) und $\beta$ ) erwähnten. Ferner aber besonders die stellen, wo ein dabeistehendes anon oder ein adverb ähnlicher bedeutung diesen sinn des praes. hist. unzweifelhaft macht.

T. Somp. 318. An oon the knight bifore the juge is brought.

T. Cl. II, 104. And in sche goth withouten lenger let.

Ebenso T. Miller 502; T. Reeve 143; T. Squyer I, 164; T. Prioresse 177; T. Monk 219; Troilus I, 324. III, 699 ; Dido 153; 287; Tesbe 100-101 u. andere.

Hierher gehören anch die fälle, wo eine adverbiale bestimmung wie therwithal eine folgende handlung als gleichzeitig mit der vorhergehenden darzustellen sucht.

T. Miller 600. He cowheth first, and knokketh therwithal ...

Tesbe 177. And therwithal she lyfteth up his heed Ypermystre 105.

And therwithal a costrel taketh be tho And seyde.

э) So kann ganz allgemein auch das energische einer handlung das praes. hist. hervorrufen.

T. Pard. 389. And forth he goth, no lenger wold he tarye.

T. Doct. 247. Sche riseth up, and to hir fader sayde.

T. Schipman 379.

And up he goth, and maketh it ful tough.

Ebenso T. Schipman 75-77, 250; T. N. Pr. 214; (Ch. Dream 663) und so oft.

b) Die bewegung ist innerlich, d. h. sie bezielit sich auf vorgänge seelischer natur.

Das praes. hist. wird hervorgerufen: 
a) durch das heftige derartiger bewegung. So besonders in klagen:

T. Frank 91. Sche mourneth, waketh, wayleth, fasteth, pleyneth, ...

Ebenso T. Knight $361-64$ (6 praes. hist.); T. Miller $432-33$ (4 pr. h.); T. March 828 (2 pr. h.), 848; T. Frank 89, 388; Troilus V, 211 (3); Anelida 172-77 (8); Dido 240-41 (4), 385-90(8).

Im wutausbruch:

Troil. V, 207. He curseth Jove, Apollo, and ek Cupide;

He curseth Ceres, Bachus and Cipride...

Die innere unruhe:

Troil. V, 561. Fro thennes-forth he rydeth up and down, ...

3) durch das unermidliche derselben. So besonders im ausdruck der freude, des fröhlichen festjubels und der zärtlichen liebkosung.

T. Frank 369. He nought entendeth to no suche matere,

But daunceth, justith, and maketh good cheere.

Adriane 272. There festen they, there dauncen they and synge

'T. March 579. He lullith hir, he kissith hir ful ofte;

ib. 116i. He kissith hir, and clippith hir ful ofte, ...

Ebenso T. March 583, 704; T. Schipman 327-328; Troilus III, 1669-70 (5 pr. h.) u. öfter.

B. Das praes. hist. im stillstande der erzählung.

Das praesens, dessen zeitbegrenzung fast ganz von dem belieben (der anschauung) des sprechenden abhängt, hat weit mehr, als das praeteritum, die fähigkeit, sich dem subjektiven bedturfniss des redenden anzupassen, und zwar sowol wenn dieser rasch von tat zu tat eilen will und so die dauer der verwirklichung der verbalbegriffe möglichst kurz darstellen muss, als anch ungekehrt, wenn er mit interesse bei einer situation zu verweilen und so die zeitsphäre der verwirklichung des verbalbegriffes möglichst auszudehnen wlinscht. Während es aber bei dem praes. hist. sub A nur darauf ankam, alle nebenbegriffe [und damit auch den zeitbegriff] gegenüber dem verbalbegriff möglichst zu unterdrticken, um so die ganze wucht des accents auf diesen konzentrieren zu können, so gilt es hier da die objektiv im ricken des hörers liegende situation ihm subjektiv nahe gebracht werden soll, um ihm so ein tieferes versenken in dieselbe zu ermöglichen] gerade den zeitbegriff der gegenwart zu betonen. Das praesens steht also hier auf 
grund seiner eigenschaft als zeitform der gegenwart und nicht wie oben als notbehelf und aus mangel einer verbalform, in welcher der temporale begriff gänzlich eliminiert werden könnte [wie etwa im infinitivus historicus], und es erklärt sich hier nur aus psychologischen grüden.

Dies praes. hist. kann stehen:

I. in der schilderung;

II. in der reflexion, welche der verfasser an eine situation der erzählung anknüpft.

1. In der schilderung.

1. In der eigentlichen schilderung.

a) Besonders beliebt ist das praes. hist. in der einleitenden schilderung, in welcher der schriftsteller sein publikum uber die besonderen örtlichen und zeitlichen nebenumstände, uber den charakter der eingefuhrten personen, ihre äussere lage, ibre verhältnisse, ihre gewohnheiten, ihr äusseres u. s. w. orientiert.

T. Clerk II, 225-28. This Walter

In Goddes pees lyveth ful esily

At home, and outward grace ynough hath he.

T. Pard. 4. Wher as with lutes, harpes and gyternes,

Thay daunce and play at dees, bothe day and night

And ete also, and drynk over her might, ...

T. Sire Thopas 16.

His rode is lik scarlet en grayn ...

Phillis 11. Distroyed ys of Troye the citee.

Ebenso und ähnlich T. Knight 479-80, 633-38 (die herrliche schilderung des erwachenden morgens). T. Miller 162-63; T. March 651; T. Doctour 41; T. Schipman 36-37; T. Sire Thopas $49,55,171,174,190,202$ u. öfter.

Hierher gehören auch die eine handlung vorbereitenden schilderungen wie Ypersmystre 46:

The array ys wroght, the tyme ys faste by

And thus Lyno hath of his fadres brother

The doghter wedded, ... u. andere.

b) Ebenso steht es gern in der abschliessenden, rasch uiberleitenden schilderung. Der verfasser wirft, ehe er sich von der eben dargestellten handlungsreihe, episode oder schilderung zu einer neuen wendet, noch einen kurzen ruckblick anf die erstere und fasst die hervorgerufene situation, an welche die neue handlungsreihe ankntipfen soll, summarisch in einer kurzen schilderung zusammen.

T.Squ.I, 212. Of sondry thoughtes thus they jangle and trete. 
'T. Ch. Y. 375. Thus maketh he is introduccioun.

T. Kn. 1900. Nature hath now no dominacioun.

ib. 2243. For now is Palomon in al his wele, ...

Ebenso T. Miller 467; T. Reeve 194; T. Clerk VI, 183; T. March 598; T. Squyer I, 244, 253; T. Frank 32, 72; Troilus V, 1101; Anelida 179, 19b; Cleopatra 71; Phyllis 45; Ypermystre 59 u. so oft. Oft steht es so am ende einer strophe: Parl. of Foules 532, Troilus I, 1092. III, 1631 u. s. w.

Anmerkung. Stellen wie T. Knight 2249:

Thus endeth Palomon and Emelye

sind nicht als praes. hist. aufzufassen, sondern als praes. logicum, indem die namen kurz gebraucht sind für 'die geschichte von'.

c) Ueberhaupt in irgendwie eingehenden schilderungen, auch mitten im gange der handlung.

T. Frank $516-19$.

Janus sit by the fuyr with double berd

And dryuketh of his bugle horn the wyn,

Biforn him stont the braun of toskid swyn,

And (nowel) crieth every lusty man.

'T. Schipman 82.

His bookes and his bagges many oon

He hath byforn him on his counter bord.

Dido 273-77.

Upon a thikke palfrey, paper white,

Sitte Dido, al in golde and perrey wreighe.

And.she is faire as is the bryghte morwe.

Ehenso T. Knight 1648; T. Frank 765; T. Schipman 90; Ypermystre $49-54$ (5 praes. hist.) n. öfter.

Anmerkung. Die fortschreitende handlung steht hier, un den gegensatz auch im tempus auszudrücken, gern im praeteritum.

'T. Miller 237. This sely carpenter hath gret mervaile

Of Nicholas, or what thing $\mathrm{may}$ him ayle,

And seyde...

und so oft. Oft steht jedoch dieselbe ebenfalls im praes. hist.

Lucrecia 153. She sytte in halle with a sorowful syghte.

Hir frendes axen what hir aylen myghte,

und öfter.

And who was dede, and she sytte aye wepynge.

Ein besonders wirksames mittel zur erhöhung der lebliaftigkeit der schilderung ist die anrede des erzählers einerseits an sein publikum, andrerseits, und dies ist noch wirksamer, an die personen der erzïhlung. Beide arten der anrede stehen meist im praet. hist.

a) an sein publikum. 
T. Kn. 1270. Ther maistow se comyng with Palomoun Ligurge himself, the grete kyng of Trace.

ib. 1638. Ther mayst thou see devysyng of hermeys.

Ebenso T. Clerk II, 69 und an anderen stellen.

$\beta)$ an die personen der erzählung. Hier besonders ist das praes. hist. das vorwiegende tempus.

T. March 544-47.

0 January .. se how thy Damyan,

Thyn oughne squier and thy borne man,

T. Frank 362-65.

Entendith for to do the vilonye.

0 , blisful art thou now, thou Dorigen,

That $\mathrm{h}$ ast thin lustry housbonde in thin armes,

That loveth the, as his owen hertes lyf.

Ebenso T. Lawe 533-34, 673-77, 705-6; T. Ch. Y. 67, 68, 70, 72; T. Monk 87; Troilus I, 524; Philomene 112-13 u. öfter.

d) So ist das praes. hist. auch geeignet zur hervorhebung des gegensatzes einer situation, an der die erzählung eben angelangt ist, gegentuber einer fruheren, welche oft im praeteritum daneben gestellt ist.

T. Monk 82. Ther was no bond with which men might him bynde.

But now is he in prisoun in a cave.

Troilus IV, 1126.

And thus she lith, with hewes pale and grene,

That whilom fressh and fairest was to sene.

Ebenso T. Monk 379, 382, 384; Troilus IV, 840; T. Reeve 77-78 und öfter.

2. Das praes. hist. steht oft, wenn ein besonderer ton auf der art und weise ruht, in der sich ein vorgang vollzieht. Dies kann stattfinden:

a) durch bilder und gleichnisse, welche mit demselben in parallele gesetzt werden.

a) Bilder.

T.Reeve 187. Wery and wete as bestys in the reyn

Comth sely Johan, and with him comth Aleyn.

'T. Lawe 957. . . . as domb sche stant as a tree.

T. Clerk III, 90.

And as a lamb sche sitteth meeke and stille.

'T. Schipman 209.

And forth sche goth, as joly as a pye.

Ebenso T. March 769; T. Somp. 96; T. Knight 740; T. Squyer I, 162-63; T. Schipman 369; T. Prioresse 222; Ypermystre 122 und öfter. 
B) Gleichnisse.

T.Squ. I, 174. It $\operatorname{stan} t$, as it were to the ground i-glewed.

Troilus IV, 1404.

And as the bryddes, whan the sonne is shene,

Deliten in hire songes, in leves grene,

Right so the wordes that they spak ifeere

Deliten hem, and make hire hertes chere.

Ypsiph. 217. Or as a welle that were botomeles,

Right so kan Jason ne have no pes. u. öfter.

b) durch adverbiale bestimmungen der art und weise oder durch sonstige, näher schildernde zusätze.

Dieselben bezeichnen

$\alpha$ ) das feierliche einer handlung, eines auftrittes, einer erscheinung.

T. March 459. Forth comth the preost, with stoole about his necke.

T. Lawe 218. 'To schippe is brought this woful faire mayde Solempnely, with every circumstance.

Ebenso T. Squyer I, 170-71, 260, Adriane 259 u. öfter.

$\beta)$ das rührende, mitleiderregende, ergreifende.

T. Lawe 821 . Hire childe crieth and sche py tously.

T. Cl. V, 113. The folk hir folwen wepyng in hir weye. Ebenso und ähnlich T. Lawe 872, 1055-56: T. Clerk V, 110; T. Frank 610-13; T. Monk 373, 421; Lucrecia 153, 155-56 und öfter.

Bisweilen erfolgt nur die besondere betonung der art und weise durch das adverb (how), während das ruhrende in den verbalbegriffen selbst liegt.

Tesbe 167-73. Who konde write... (164)

And how she lyth and swowneth on the grounde?

And how she wepe of teres ful his wounde?

How medeleth she his blood with hir compleynte?

How with his blood hir selven gan she peynte?

How clippeth she the dede corps? allas!

How dooth this woful Tesbe in this cas?

How kysseth she his frosty mouthe so colde?

und ähnlich öfter.

r) kurz das aussergewöhnliche bezw. spezifisch eigentümliche einer einzelnen handlung; dies geschieht

aa) durch adverbien, und zwar

$\alpha \alpha)$ durch selbständige adverbien.

'T. Miller 248. This knave goth him up ful sturdily...

T.Reeve 142. And to the hors he goth him faire and wel.

'T. Lawe 632. Unto the kynges moder he goth ful swithe.

And salueth hire fair in his langage. 
Ehenso T. Miller 224, 460; T. Reeve 137; T. Clerk VI, 84; T. March 696; T. Sire Thopas 119; Lucrecia 79-80; Ypermystre 118 und so sehr oft.

$\beta \beta)$ durch adverbien, welche auf eine folgende oder vorangehende ausfuhrlichere schilderung hinweisend, diese in beziehung zu der handlung setzen, auf welche sie sich beziehen.

'Troil. V, 859. Fro that demaunde he so descendeth doun To axen hire.

ib. V, 1524. And so descendeth doun from gestes olde To Diomede, ... .

Ebenso Philomene 59; (Ch. Dream 1589) u. öfter.

Hierher sind auch die zahlreichen durch thus eingeleiteten praes. hist. zu zählen, welche sub $1, \mathrm{~b}$ von einem anderen gesichtspunkte aus betrachtet sind.

Unmittelbar hieran schliesst sich der gebrauch des praes. hist. im vordersatz des consecutiven satzgeftiges. S. unten $6, \mathrm{~b}$.

bb) durch sonstige schildernde zusätze.

'T. Miller 464. Withouten wordes mo they goon to bedde.

ib. 553. And Absolon goth forth a sory paas.

'T. Clerk II, 106.

He by the hond than takith this olde man, ...

Ebenso T. Lawe 311; T. Somp. 462; T. Frank 765; (Flower and Leaf 419-20); Cleopatra 121; Tesbe 97 u. so oft.

Besonders deutlich zeigt sich der einfluss der besonderen betonung der art und weise auf die setzung des praes. hist. da wo dasselbe mit einem adverb der art und weise unmittelbar neben dem praeteritum steht.

T. Miller 454. This carpenter seyd his devocioun, And stille he sitt, ...

'T. Lawe 961. He wept and him excuseth pitously.

Pr.Bathe 803. And ner he can, and knelith faire adoun.

Ypsiph. 182. He loketh pitousely, but noght he sayde. u. öfter.

3. Das praes. hist. steht gern bei handlungen und zuständen längerer dauer.

$\alpha)$ Der verbalbegriff selbst schliesst den begriff einer längeren dauer in sich. So besonders to wayte.

T. Clerk IV, 99.

He wayteth, if by word or countenaunce ...

Ebenso T. March 852; T. Squyer I, 79-80; T. Frank 563; T. Prioresse 134 u. öfter.

to dwelle: T. Frank 85.

And $d$ welleth there two yeer. 
to sojourne: Troilus $\mathrm{V}, 213 \mathrm{u}$. öfter.

And in this wyse he neigh til day sojourneth.

to lyve: 'T. Clerk VI, 190 u. öfter.

Ful many a yer in heigh prosperité

Lyven these two in concord and in rest. $u$. andere.

$\beta$ ) Der begriff der dauer wird durch eine zeitbestimmung hervorgerufen.

T. Prior. 183. Upon his beere ay lith this innocent ...

T. Monk 189. . . . and ever he is afere

To doon amys or more to trespace.

Ebenso T. Reeve 279, 302; 'T. Clerk VI, 81; T. March 507; T. Frank 561; T. Monk 357; Troilus IV, 670. V, 771-72, 1444-45 und öfter.

Anmerkung. In folgendem beispiele kann man die ursache des praes. hist. deutlich beobachten:

T. Lawe 768. And ever sche prayeth hir child to hold his pees, And took hir leve, and with an holy entente

Sche blesseth hire, and to the schip sche wente.

Das praet. trägt die schlichte handlung, während da, wo zusätze der dauer oder der art und weise hinzukommen, sofort das praes. hist. erscheint.

4. Hierher gehören auch die fälle, wo das praes. hist. in der indirekten rede steht, indem die worte, gedanken oder absichten der handelnden personen, oder besonders wichtige stellen aus schriftstiucken, briefen u. s. w. dem verfasser so lebhaft vorschweben, dass er sie gleichsam zu hören glaubt und sie desshalb in das praesens setzt.

a) So beginnt er die indirekte rede oft mit dem praeteritum und verfällt mit dem wachsenden interesse, das der inhalt der darstellung erweckt, in das praesens.

T. Knight 1661.

Som sayde he lokede grym and wolde fyghte;

He hath a sparth of twenti pound of wighte.

ib. 1847. Men seyde eek, that Arcita shoulde nought dye, He schal be helyd of his maladye

S. T. 2705. E. H. C. Corpus und L. zeigen auch das erste mal schal, nur P. stiitzt shuld.

T. Miller 105. And swor hir oth by seynt 'Thomas of Kent,

That sche wolde be at his commaundement,

Whan that sche may hir leysir wel aspye.

T. Lawe $140-43$. They ben acordid, ... that ... alle his lieges schuld i-crystned be,

And he schal have Constance in mariage.

Troil. V, 859. Fro that demaunde he so descendeth doun

To axen hire, if that hire straunge thoughte 
The Grekis gyse, and werkes that they wroughte?

And whi hire fader tarieth so longe

To wedden hire unto som worthy wighte?

Ehenso T. Lawe 246-49, 652-58; 'T. March 385-86; Troilus V, 771-75, 1430-31; Ypsiphile 50-52 u. öfter.

b) Die indirekte rede beginnt gleich mit dem praes. hist.

T. Lawe 988. Som men wolde seye, that hir child Maurice

Doth his message unto the emperour ...

T. March 839. For whan he wist it may noon other be

Troilus I, 90. And sayden that he and alle his kyn atoones

Ben worthy for to brennen alle fel and bones.

Ebenso T. Lawe 314-15; T. Clerk IV, 135-36; T. March 971-72; Troilus I, 83. III, 1678-79. IV, 117-19; Ypsiphile 201-2 u. öfter.

Die lebhaftigkeit dieser darstellungsweise wird bisweilen so gross, dass der verfasser ohne jede vermittlung in direkte rede fällt. So:

Dido 365. This Dido hath suspecion of this, And thoughte wel that hit was al amys;

For in his bedde he lythe a nyght and siketh,

She asketh him anoon what him mysliketh;

'My dere herte which that I love mooste?'

Ypsiphile 159-75 stellt alle drei stadien dar. Die rede des Ercules wird in indirekter rede angefthrt und so steht anfangs das praeteritum. 160-164 fällt jedoch der verfasser schon in das praes. hist. - Das praeteritum tritt dann wider ein, um 171-175 jedoch plötzlich in direkte rede tberzugehen, die freilich von den herausgebern nicht als solche angezeigt ist [weder von Morris V, s. 324, noch von Gilmans III, s. $138_{1536-40]}$.

Anmerkung. Hier schliessen sich einige stellen an, wo es sich allerdings nicht um indirekte rede handelt, die aber insofern mit den hier behandelnden fällen übereinstimmen, als eine im praet. stehende, einen fortschritt bezeichnende handlung [dort sayde - hier eine beliebige handlung] nach ihrem inhalt näher erläutert und ausgefiihrt wird - ausfilhrungen, die im praes. hist. geschehen.

T. Frank 169. And schopen for to pleyen somwhere elles.

(sc.) They leden hire by ryveres and by welles, And eek in other places delitables;

They dauce and playe at chesse and at tables.

Ypsiphile 197-200.

A letter sente she to hym certeyn,

And him repreveth of his grete untrouthe,

And prayeth him on hir to have some routhe. 
Cleopatra 10-12.

So fil yt, as Fortune hym oght a shame

Rebel unto the toune of Rome ys hee.

Duchesse 66. So it befil, therafter sone,

This king wol wenden over se.

Und an anderen stellen, doch nicht häufig.

c) Einen noch höheren grad von lebhaftigkeit erreicht der schriftsteller, wenn die indirekte rede, welche im praes. hist. steht, gar nicht durch ein verbum dicendi eingeleitet ist. [Das praes. hist. erweckt hier unwillkurlich die vorstellung direkter rede.] Diese ausdrucksweise ermöglicht bei aller deutlichkeit eine kürze, welche die lebendigkeit und frische der darstellung bedeutend erhöht.

T. March 371. Nedith no more for him to gon ne ryde.

ib. 382. Suffisith him his youthe and hir beauté.

T. Pard. 248. Deth schal be deed, if that they may him hente.

Troilus IV, 647.

That al this world ne myghte hire love unbynde,

Ne 'Troilus out of hire herte caste;

She wol ben his whil that hire lif may laste.

Dieses beispiel ist sehr deutlich. Nachdem der schriftsteller bis v. 648 die empfindung der Criseyde objektiv geschildert hat, glaubt man sie, v. 649 , plötzlich selbst reden zu hören. Ebenso 'T. Frank 710-11; Troilus V, 186-87, 1112-13; Cleopatra $50--51,92$ u. öfter.

Die frage, ob direkte oder indirekte rede, ist im folgenden beispiel gar nicht zu entscheiden.

Troilus II, 1583 (wir citieren die ganze stelle):

After compleynt hym gonnen they to preyse, As folk don yet when som wight hath bygonne To preyse a man, and up with prys him rayse A thousande fold yet heighere than the sonne; He is, he kan, that fewe lordes konne, And Pandarus, of that thei wold afferme, He naught forgat hire preysynge to conferme.

5. Das praes. hist. steht oft, um die wichtigkeit gewisser nebenumstände für den späteren verlauf der handlung anzudeuten. [Wenn dieselben im praet. stehen, so werden sie meist durch now eingeleitet (vgl. das deutsche nun, nun aber). Troilus I, 113: Non was this Ector pitous of nature $\mathrm{u}$. so oft.]

T. Reeve 236. The cradil at hire beddes feet is set, To rokken, and to yive the child to souke.

T. Lawe 934. This Alla $\mathrm{h}$ ath the face in remembraunce

of dame Custannce, and thereon mused he ... 
T.Schipm.62. This nobil monk of which I yow devyse, $\mathrm{Hath}$ of his abbot, as him list, licence, ...

Philom.132. But letteres kan she weve to and froo ...

Meist finden derartige nebenumstände ihre stelle im relativsatz, und zwar kann der letztere schildernd, determinierend, bezw. näher bezeichnend, näher erklärend oder beschränkend sein.

a) Schildernd.

T. Kn. 2022. Whan it was day he brought hem to the halle, That roreth of the cry and of the soun.

T. Lawe 592-94. Jhesus ......

Made Alla wedde ful solempnely

This holy mayde, that is bright and schene.

Ebenso T. Miller 471-72; T. Lawe 621; T. March 498, 713, 1084; T. Squyer I, 182; Philom. 7-8. Auffällig erscheint das praes. hist. in Fame III, 111 (Gilmans ib.):

There herd I pleyen upon an harpe

That sowneth bothe wel and sharpe

Orpheus ful craftely.

Man möchte dabei wol an ein praes. logicum denken, - doch spricht der zusammenhang zu deutlich dafür, dass es praes. hist. sein muss.

b) Determinierend, bezw. näher bezeichnend.

T. Kn. 1039. In al the lond ther nas no craftys man, That geometry or arsmetrike can.

T. Miller 572. A soofte paas went he over the strete Unto a smyth, men clepith daun Gerveys, ...

T. Schipm.95. A mayde child com in hir compaignie, Which as hir list sche may governe and gye.

Ebenso T. Somp. 60; Troilus IV, 657. V, 460; Adriane 75, 257 und öfter.

c) Näher erklärend.

T. Clerk IV, 152.

This marquys writen hath in special

A letter, in which be schewith his entente.

T. March 752. Right of hir hond a letter makede sche,

In which sche grauntith him hir verray grace. u. üfter.

d) Beschränkend.

T. Miller 232. He nolde answere, for nought that $m$ ay bifalle.

Lucrecia 125. She axeth grace, and seyde al that she kan. u. öfter.

Das praes. hist. im relativsatze macht oft den eindruck, als habe der erzähler den standpunkt der erzählung in einer gewissen nachlässigkeit fallen lassen und sei in seinem eigenen fortgefahren. Dazu sind besonders die beiden folgenden bemerkenswerten stellen zu vergleichen: 


\section{T. Frank 94-95. Hire frendes ...}

Conforted hire in al that ever they mighte or may.

'Troil. I, 473. And yet was he, wher-so men went or riden,

Founde oon the best, ...

Doch ändert das wenig an der tatsache; denn ob mit absicht des verfassers oder nicht, zweifellos ist es, dass die lebhaftigkeit der darstellung das praesens auch in diesen fällen veranlasst hat. Oefters wird das praes. hist. im relativsatze durch das praes. hist. des regierenden hauptsatzes hervorgerufen: so T. Squyer I, 171; T. Frank 520, 526; T. Doct. 158-59; Troilus I, 84. V, 187; Lucrecia 124 und so oft, doch im allgemeinen scheint die consecutio temporum auf setzung oder nichtsetzung des praes. hist. so gut wie keinen einfluss zu haben, wie aus den im ganzen abschnitt angefuhrten beispielen zur gentuge hervorgeht. -

Entsprechend dem sub 2 und 3 angefuhrten gebrauche des praes. hist. steht dasselbe gern in folgenden satzarten.

a) in vergleichungssätzen, and zwar sowol realer wio irrealer art (vgl. 2, a).

a) im realen vergleichungssatz: und zwar steht das praes. hist.

aa) sowol im vorder- wie im nachsatz.

$\alpha \alpha)$ vergleich der gleichheit.

T. Kn. 610. By helpyng of a freend brak his prisoun, And fleeth the cite fast as he may goo.

T. Cl. II, 81. And cometh hom as soone as ever sche may.

Ebenso T. Knight 617, 1857 (die vergleichungspartikel ist ausgelassen: as he wel can, vgl. Hertzberg 2717 'so gut er kann'); Pr. Somp. 33; Troilus V, 1100-1 u. öfter.

$\beta \beta)$ vergleich der ungleichheit.

'T. Cl. VI, 50. For she is fairer, as they demen alle,

Than is Grisild, and more tender of age. u. öfter.

bb) Nur im nachsatz.

T. Lawe 1001. As ferforth as his connyng may suffise.

Lucrecia 75. And ay the more he was in dispaire,

The more he covetyth ...

Ebenso T. Clerk I, 124. IV, 131; T. March 691 u. öfter.

ce) Nur im vordersatz.

$\mathrm{T}$, March 769. And eek to January he goth as lowe

As ever did a dogge for the bowe.

Ypsiph. 181. Thise Jason is as coy as ys a mayde.

Das praesens im nachsatz ist praes. log. - und so öfter. 
B) im irrealen vergleichungssatz. - Hier kann das praes. hist. nur im vordersatze stehen, während der vergleich als irreal gedacht im conj. praet. zu stehen pflegt.

T.Reeve 231. He yoxeth, and he speketh thurgh the nose As he were on the quakke or on the pose.

T. Prior. 142. Sche goth, as sche were half out of hir mynde, To every place.

T. N.Pr. 359. He lokith as it were a grim lioun.

Ebenso T. Squyer I, 174; T. Frank 810 u. öfter.

b) im consecutiven satzgeftige. Zwischen a) und b) stehen beispiele wie folgendes:

T. March 500. Queen Esther lokede never with such an ye On Assuere, so meke a look hath sche;

a) im haupt- oder vordersatz.

T. Kn. 2245. And Emely him loveth so tendirly, And he hir serveth al so gentilly, That ...

T. Miller 162. This parisch clerk, this joly Absolon Hath in his herte such a love longyng, That...

T. Lawe 561-63. This Alla kyng hath such compassioun .. That . . Ebenso T. Clerk III, 3. VI, 173; T. March 498, 799; Troilus IV, 20, 342, 650; Anelida 186; Dido 83; Philom. 120; Ypermystre 123,124 a. öfter.

Im unsicheren $\mathrm{Ch}$. Dream 2021 u. öfter.

Der hauptsatz kann anch nachstehen:

Phyllis 20. Hym were lever than al the worlde a-londe, So hunteth hym the tempest to and fro. u. so öfter.

$\beta$ ) im nachsatz, dem eigentlichen consecutivsatz. Die handlung desselben erhält durch den vordersatz einen aussergewöhnlichen accent.

T. Cl. II, 216. And couthe so the poeples hert embrace, That eech hir loveth that lokith in hir face.

T. Monk 430. And mete and drynk he hadde So smal that wel unnethe it may suffise

Philomene 65--66.

He caste hys firy hert upon hir soo,

That he wol have hir how-soo that hyt goo, ...

Ebenso T. Reeve 100; T. March 448-51, 734-36; T. Squyer I, 260-63; Troilus IV, 27-28, 315; Anelida 120, 184; Fame III, 590-92; Lucrecia 137-39; Adriane 18-20; Ypermystre 29 u. öfter.

In Dido 295 ist der consecutivsatz zugleich wider vordersatz zu einem anderen consecutivsatz, und so ist das praes. hist. bier doppelt begrtindet. 
Doune come the rayne, with haile and sleet so faste,

With hevenes fire, that ys so sore agaste

This noble quene, and also hire meynee,

That ...

y) Sowol im vorder- wie im nachsatze.

T. Knight 117-19.

The reede statue of Mars with spere and targe

So schyneth in his white baner large,

That alle the feeldes gliteren up and doun.

T. Cl. VI, 78. With s o glad chier his gestes sche receyveth,

And so connyngly everich in his degre,

T. March 771-73.

That no defaute no man aparceyveth,...

$\mathrm{He}$ is so plesaunt unto every man,

That every wight is fay n to speke him good.

Ebenso T. Knight 419-20, 596-98, 635-36, 816-18, 1335-37, 1627-28; T. Miller 185-86, 200-201; T. Lawe 309-10; T. March 346-48; 631-32, 849-51; T. Pardoner 10-11; T. Prioresse $103-5$ u. öfter.

In umgekehrter stellung.

T. March 605. The slakke skyn about his nekke schaketh,

Whil that he song, so chaunteth he and craketh.

Dido 266. An huntynge wol this lusty fresshe queene,

So priketh hire this newe joly woo. u. ofter.

c) In sützen, in denen die vorstellung der dauer einer handlung besonders hervorgehoben wird; vgl. 3. s.556.

a) Im haupt- bezw. vordersatz zum temporalsatz mit til, der dem vordersatz des consecutiven satzgeftiges sehr nahe steht.

'T. Reeve 301. And forth sche goth, til sche the cradil fand.

'T.Schipm.318. In mirth al night a bisy lif thay lede

$T$ il it was day.

Dido 45. So longe he walketh in this wildernesse, 'Til at the last ...

Ebenso 'T. Reeve 139; 'T. Lawe 1060; T. Clerk II, 97-98; 'T. Frank 78-79; Phillis 26-28 u. öfter.

whan steht in fast gleicher bedeutung mit il in

T. Lawe 495. He wayteth whan the constable was aweye, .. u. öfter

B) Im temporalsatz mit whil, whiles, jedoch nur, wenn derselbe die gleichzeitigkeit zweier handlungen ausspricht; im Lateinischen ist das praes. hist. nach dum regel.

aa) mit whiles.

'T. Squ. I, 69. Whil that the kyng sit thus in his nobleye,

T. Monk 327. Ne never might her founen doon hem tle

Ay while that Odenakes dayes laste. 
Kommt das praes. hist. nach whiles unter anderen als obigen bedingungen vor, so ist es aus anderen ursachen zu erklären und gehört nicht hierher.

bb) mit as.

T. Reeve 194. Thus pleyneth Johan, as he goth by the way.

T. Clerk V, 113.

The folk hir folwen wepyng in hir weye, And fortune ay thay cursen as thay goon.

T. Prioresse 56 u. öfter.

II. In der reflexion.

1. Wenn der verfasser eine reflexion an eine situation oder an ein ereigniss der erzählung anknupfen will, so tut er dies meist im praes. hist., nm dadurch, dass er dem gegenstande der reflexion das gepräge des unmittelbar vorliegenden, gegenwärtigen verleiht, das interesse des hörers oder lesers zu erhöhen.

T. Kn. 599. And eek therto he is a prisoner

Perpetually, nat oonly for a yeer!

T. Cl. III, 9. He . . . fond hir ever good, what needith it

Hire to tempte?

Pr.Maunc. 89. [What needith it? he drank ynough biforn.]

Troil.IV, 174. This folk desiren now delyveraunce

of Antenor, that brought hem to myschaunce.

ib. V, 1842. Swich fin hath, lo! this Troilus for love!

Swich fyn hath al his grete worthynesse!

Swich fyn $h a t h$ his estat real above!

Swich fyn his luste, swich fyn $\mathrm{h}$ ath his noblesse.

Swich fyn hath false worldes brotelnesse!

Interessant ist hier, dass im letzten verse das praes. log. ganz unmittelbar neben dem praes. hist. steht.

Ebenso steht das praes. hist.: T. Miller 199; T. Lawe 401; T. Frank 108; Troilus V, 449, 1565; Dido 400; Lucrecia 118-25 und so sehr oft.

Solche reflexionen erhalten oft einen sehr lebhaften charakter dadurch, dass der dichter die personen der erzählung anredet. Auch hier steht das praes. hist. mit vorliebe.

T. Prior. 122. 0 cursed folk! 0 Herodes al newe!

What may your evyl entente you availe?

Adriane 67. Wel may stow wepe, 0 woful Theseus,

That art a kynges sone, and dampned thus!

Ebenso T. Prioresse 126 u. öfter.

2. Hierher sind auch die (thrigens nicht gerade zahlreichen) stellen zu zählen, in denen das praes, hist, den inhalt einer fol. 
genden episode im voraus kurz angibt und so gewissermassen die funktion einer $\mathfrak{u}$ berschrift thernimmt.

'T. Lawe 368. 0 many a sory mele may sche bayte, After hir deth ful ofte may sche wayte, Or that the wilde wawe wol hir dryve Unto the place theras sche schal arryve. u. offter.

B efmerkungen. 1. Während es sehr erklärlich ist, dass in den fällen sub A sich hauptsächlich verba der bewegung im praes. hist. finden, so ist es andrerseits doch bemerkenswert, dass in den fällen sub $B$ ein auffällig häufiges vorkommen der hilfsverba besonders von may und can zu beobachten ist.

2. Wie sehr sich das praes. hist. in der sprache Chaucer's schon befestigt hatte, zeigen die zahlreichen stellen, in denen es ohne weiteres neben dem praes. log. vorkommt. Eine verwechslung der durch die beiden tempora bezeichneten, verschiedenen zeitsphären war also schon völlig ausgeschlossen. Hier ist jedoch zu erwähnen, dass sich bei Chaucer das praesens hin und wider in präteritaler darstellung findet, ohne ein praes. hist. zu sein. Es ist dann ein wechsel des standpunktes anzunehmen, der teils aus einer gewissen lebhaftigkeit, teils aber auch aus einer unverkennbaren nachlässigkeit zu erklären ist.

Astrolabe II, § 1,8. Tho leide I my rewle ouer this forseide day \& fond the point of my rewle in the bordure vp-on the firste degree of aries; ...\& thus $\mathrm{knowe} I$ this conclusioun ...

ib. II, $\S 40,12$. \& thanne set $I$ the point of $F$ vpward . . . . . (15) \& thus hauy 2 degrees by-twixe my to prikkes; than leide I down softely my compas...

ib. II, $\S 40,37$. \& thanne set I the point of $F$ downward in the same signe ... (39) \& thus hauy 3 degrees by-twixe bothe prikkes; thanne sette $I$ the degree...,

[dass set in beiden fällen praeteritum ist, ist nach dem vorangehenden (36) tho tok I und nach dem folgenden (11) tho tok I my label \& leide il fix ... anzunehmen].

Boëthius I, 192-94. pei ... to drow e n me criynge, ...... and tornen and to renten my clopes [C. zeigt jedoch koruen statt tornen].

ib. l, 15\%. derknesses forleften we, and to myn eyen repeyre ageyne her firste strenkep [C. zeigt jedoch repeyrede].

3. Um einen ungefähren iiberblick über die ausdehnung des praes. hist. bei Chaucer zu ermöglichen, geben wir eine statistische zusammenstellung der erzählenden tempora in der Knightes und der Clerk of Oxenfordes 'Tale, deren stil für Chancer wol als mustergiltig bezeichnet werden darf. Hierbei sind sämmtliche tempora der direkten rede, sämmtliche rein persönlichen bemerkungen des dichters (as I you tolde first, of which $I$ first bigan u. dgl.), sowie sämmtliche stellen, wo die verbalform sowol praesens wie praeteritum sein kann (wepen bothe yong and olde u.dgl.) ausgeschlossen worden. In der Knightes 'Tale sind von 1021 temporibus der erzïhlıng 970) solehe der werdenden, il der vollendeten handlung. 
Von diesen 970 entfallen 727 - mithin ca. $75 \%$ - auf das praeteritum, 213 - mithin ca. $22 \%$ - auf das praes. hist. und 30 - mithin ca. $3 \%$ auf das perf. hist. I (vgl. Perfectum).

Etwas ungünstiger für das praes. hist. stellt sich das verhältniss in der Clerk of Oxenfordes Tale, wo von 491 temporibus der fortschreitenden handlung 389 - mithin ca. $77 \%$ - auf das praet., 83 - mithin ca. $17 \%$ auf das praes. hist. und 19 - mithin ca. $4 \%$ - auf das perf. hist. I entfallen. - In summa findet sich das praes. hist. in den Canterbury Tales ca. 1150 mal. - Im afr. Rolandsliede findet es sich nach Bockhoff s. 15 1500 mal. Dabei ist jedoch zu beachten, dass einerseits die Tale of Melibeus und die Persones Tale bei obiger aufstellung nicht mit in betracht kommen, andrerseits auch die zahlreichen prologe ibrer natur nach nur sehr wenig erzählende tempora enthalten, so dass diese zahl an sich geringer erscheint, als sie tatsächlich im vergleich zu den iibrigen erzïhlenden temporibus sich stellt.

Besonders stark vertreten ist das erzählende praesens in folgenden Tales: T. Knight, T. Miller, T. Reeve, 'T. Lawe, T. Clerk, T. March, T. Squyer - etwas weniger stark, aber immer noch in stattlicher anzahl, in T. Frank, T. Schipman und in Sire Topas. Auffallend spärlich zeigt es sich in der T. Somp. $(9 \mathrm{mal})$, T. Sec. Nonne $(2 \mathrm{mal})$, T. Doctour $(7 \mathrm{mal})$ und der T. Maunciple (nur ein einziges mal: vers 52).

Ausserdem ist zu bemerken, dass die Legende of 9 Goode Wymmen und die Caunterbury 'Tales sich vor allen tibrigen werken Chaucer's durch eine besonders ausgiebige verwendung des historischen praesens auszeichnen. -

§ 2. Das praesens fur das futurum.

Grimm IV, 139 u. 176 ff. - Heyse II, 6, 757. - Koch $\S 42$ u. 46.

Mätzner II, 75: 'Bei dem mangel einer besonderen form für das futurum baben die älteren germanischen mundarten grossenteils die von dem standpunkt des redenden aus zukttnftigen tätigkeiten durch das praesens .... ausgedrtickt.'

Dieser gebrauch findet sich auch bei Chaucer, aber nur unter der bedingung, dass der futurische sinn dieser praesentia durch den zusammenhang zweifellos klarliegt. Man könnte dieses verhältniss vielleicht auch so auffassen, dass der begriff des zukthnftigen nicht im tempus, sondern auf andere weise (meist durch adverbiale zeitbestimmungen) ausgedrtickt wird. Es ist hierbei jedoch zu bemerken, dass in einzelnen fällen, wo die abstrakte, streng logische denkart futurische ausdrucksweise vorziehen wurde, es gar nicht in der absicht des redenden liegt, das zukunftige der handlung zu betonen, sondern wo er im gegenteil durch das bestreben, einen anderen begriff (als den des zuktunftigen) in den vordergrund zu stellen, 
absichtlich das futurum vermeidet. - Das futurum würde dann dem gedanken des redenden eine ganz falsche färbung geben.

I. Das praesens steht also in solchen fällen nicht statt des futurs, sondern in eigener funktion. Solche fälle sind:

1. Das praesens hat präsentische bedeutung, schliesst aber darum die zukunft von der zeitsphäre der handlung nicht aus, sondern in der anschauung des redenden bilden gegenwart und zukunft in bezug auf verwirklichung der betreffenden handlung eine zeitsphäre.

'T. Knight 316. For wel thnu wost

That thou and I been dampned to prisoun

Perpetually, us gay neth no raunsoun.

ib. 2163. ... the harde stoon

Under oure foot, on which we trede and goon,

Yith wasteth it, as it lith by the weye.

'I. Reeve 318. But evermo ...

I a m thin owen clerk.

'T. Bathe 378. I do no fors the whether of the tuo,

For as yow likith, it suffisith me.

Troilus III, 881.

I am, til God me bettere mynde sende,

At dulcarnon, right at my wittes ende u.s. w.

2. Das praes. steht in der absicht, das zukünftige ereigniss aus der entfernteren zeitsphäre in die unmittelbare gegenwart zu verlegen, um so die unbedingte sicherheit anzuzeigen, mit welcher nach thberzeugung des redenden das betreffende ereigniss eintritt, - bezw. ausbleibt.

T. Kn. 264. I nam but deed, ther nys no more to seye.

T. Miller 422. Help us to skape, or we be ded echon.

T. Miller 110,416 und so sehr häufig.

Anmerkung. Vergleiche hierzu den gleichen gebrauch im Afr., Bockhoff s. 11: mort sunt Rol. 577; morz estes ib. 3513; morz ies ib. 3955, während doch das Afr. gerade in bezug auf die verwendung des futurs ausserordentlich genau verfälırt.

3. Die präsentische anschauung geht gleichberechtigt neben der futurischen her, indem diese den ton mehr auf die zeitsphäre, jene mehr auf das geschehen an sich legt.

T. Kn. 710. Ye ben the cause wherfore that I dye. (dass. ib. 88.)

T. Miller 91. I wis, but if I have my wille

For derne love of the, lemman, I spille.

ib. 31i. To no wight thou schalt this counsel wreye

For it is Cristes counsel that I se ye ...'

'T. Reeve 179. They get hym nat so lightly, by my croun! 
T. Schipm. 323. And forth he rideth hom to this abbay, Or wher him list, nor more of him I s a y.

Pr. Persone 31. Thow get is t fable noon l-told for me. Hierher gehören dịe meisten fälle sub relativsatz, vgl. II, 2, c.

4. Der verbalbegriff drtickt an sich etwas werdendes und damit in die zukunft hineinragendes aus, so dass das praes. in bezug anf den standpunkt des redenden schon von vornherein etwas zukthftiges einschliesst.

So waxen:

T. Knight 2166. The brode ryver som tyme wexeth drye.

(som tyme $=$ einst).

So come:

T. Kn. 780-85. Right as the honter in the regne of Trace, That stondeth in the gappe with a spere And thenketh: Here cometh my mortel enemy.

T. Miller 537. For after this I hope ther cometh more u. s. w.

II. Da, wo man schliesslich das praes. zur bezeichnung einer zukthnftigen handlung findet, kann man nicht sagen, dass das praes. statt des futurums stehe, - sondern der begriff des zuktunftigen ist hier nicht im tempus, sondern anderweitig ausgedrickt und zwar

1. Im hauptsatz.

a) Durch eine adverbiale zeitbestimmung.

T. Persone 274, 12. Wher ben thanne the gaye robes, and the softe scheetis, and the smale schirtes?

ib. 302, 13. this day thay prayse, to morwe thay blame.

Troilus V, 1122. For ought I woot, by for noon sykerly, Into this town ne cometh not here Criseyde.

Fame I, 353. Eke, though I myghte dure ever, That I have do, rekever I never u. so oft.

b) Oft erhält der nebensatz die bedeutung einer futur. zeitbestimmung.

a) Temporalsätze.

T. Knight 1399. Thanne rekke I nat, whan I have lost my lyf, Though that Arcite have hir to his wyf.

M. 189, 6-8. and thanne, whan I knowe here wille and here entent, I may counseile yow the more seurly.

Troilus III, 881. I a m, til God me bettere mynde sende;

At dulcarnon u. s. w.

$\beta)$ Bedingungssätze.

Troilus I, 636. If thow do so. thi witte is wele bywared

ib. I, 694 .

Wo hym that is allone,

For, and he falle, he hath non helpe him to ryse.

ib. I, 715 .

If God wil thow art nonght agast of me. u. s. w. 
Ebenso ein versteckter bedingungssatz:

'Troilus I, 953-55.

Now looke that atempree be thi brydel,

Or elles alle oure labour is on ydel. u. öfter.

Anmerkung. Das praesens kann iberhaupt nicht nur da stehen, wo die streng logische anschauungsweise das futur erwartet, sondern auch da, wo sonst modale hilfsverben mit dem infinitiv des betreffenden begriffsverbs demselben gedanken eine feinere und schärfere niiancierung geben, auf welche es dem redenden jedoch, wenn er nur das praesens des begriffsverbs setzt, weniger ankommt.

So 1 . Mussen.

a) müssen $=$ nicht anders können (prämissen und schluss sind nicht als solche ausgesprochen).

Boëce I, 227. we scorn e swiche rauiners and honters of foulest pinges. $=$ wir müssen sie verachten.

ib. 976. per nis nat whi pou sholdest wene pi self a wreche . for pinges pat now semen soory passen also. u. so oft.

b) mitssen $=$ notwendiger schluss.

Astrolabe II, $\S 38,18$. \& yif thow drawe a cros-lyne ouer-thwart the compas Justly over the lyne Meridional, than has tow est and west.

ib. II, $\S 25,25$. \& thanne hastow the heighte of the heuedes of aries \& libra.

Ebenso ib. II, § 29, 18; § 37, 1 und sehr oft.

Aus der vorstellung, dass diese folgen notwendig eintreten, geht die vorstellung hervor, dass sie zweifellos sicher eintreten, und um diese unbedingte sicherheit auszudrticken, steht das praesens.

c) missen $=$ notwendige prämisse $\mathrm{zu}$ einem gegebenen schluss, - z. b. notwendige handlung zur erreichung einer absicht, zur erfullung einer bedingung - oft eine versteckte aufforderung.

Astrolabe II, $\$ 42,10$. \& aftyrward, whan pou seest hym (sc. pe tour) at 2, per pou settest an-oper prikke, pan pou fyndest between too prikkys 60 fett; pan pou schalt fynde pat 10 is pe 6-party of 60 . And pen is 10 fete pe altitude of pe tour. = und dann, wenn du ihn bei 2 siehst, wo du wider ein zeichen setzen $\mathrm{musst}$, findest du zwischen 2 (den beiden) zeichen 60 fuss. u. so öfter.

2. Sollen.

a) Sollen $=$ imperativ. umschreibung. Hier ist nur eine stelle $\mathrm{zu}$ belegen und selbst diese ist unsicher. Sie ist aber gerade desshalb um so interessanter, als sie zeigt, dass das praesens zum ausdruck dieser ntiance schon von Chaucer nicht mehr als geeignet empfunden wurde. 
Harl. ed. Morris: T. Persone 282, 21. And therfore seyde the aungel to Joseph, thow (schalt) clepe his name Jhesus.

Ebenso S. T.: E. 286, H und C. Aber Corpus in thereinstimmung mit $P$ und $L$ zeigt:

286 pou clepest his name ihesus.

b) Sollen $=$ futurische umschreibung in allen möglichen ntuancen.

$\alpha)$ in der prophezeiung.

T. Persone 273, 11. Agagns honours han they in helle schame and confusioun.

Vgl. dazu ib. 273, 27. Agayns riches of this world schuln thay han mysese of povert. u. so öfter.

$\beta)$ in der drohung.

T. Pard. 290. Thou partist nought so lightly, by seint Johan. u. öfter. $\gamma$ ) im versprechen.

Troilus II, 1531. Thow shalt the bettere pleyne, And hast the lasse nede $u$. öfter.

d) in der versicherung.

Pr. Persone 31. Thow get ist fable noon i-told for me.

Vgl. weitere beispiele sub I, 3. T. Reeve 179, T. Miller 92 u. öfter.

$\varepsilon)$ in der rein futurischen umschreibung. Siehe oben II.

3. Können, jedoch nur, wenn der sinn negativ ist.

Boëthius 3397. For foreine shrewednesse ne bygynnep nat fro pe corages of good folk hire propre honoure.

Vgl. dazu die ne. randglosse der herausgeber: The wickedness of another cannot deprive a virtuous soul of its own honour.

ib. 627. And forpi he pat forletep certeyne ordinaunce of doynge by ouerprowyng wey ... he ne hap no glade issue or ende of hys werkes... (dessen werke können unmöglich ein gutes ende nehmen).

Pr. Miller 43. Leeve brother Osewold,

Who hath no wyf, he is no cokewold.

(der kann natïrlich auch kein hahnrei sein). u. so öfter.

4. Wollen.

a) in eigener bedeutung (hier ist das praesens selten).

Astrolabe II, $\S 29,9$. set the point of thy gret Rewle ther thow takest thyne Altitudes, vp-on as many degrees in his bordure fro his Meridional as was the point of thy label fro the lyne Meridional .... = wo du deine höhen nehmen willst. u. so öfter.

Anmerkung. Einen ganz speziellen und interessanten fall für diese erscheinung [dass nämlich modalverba mit dem infinitiv eines begriffsverbs durch die einfachen verbalformen des letzteren, so weit es sich um das praesens oder das praeteritum handelt, vertreten werden können], bietet das lateinische imperfectum de conatu dar.

b) als futurische umschreibung. 
Astrolabe II, $\S 36,11$. set thanne the nadir of the assendent on the ende of the 4 howre, pan wol the bygynnyng of the 6 house sitte on the Midnyght lyne pe bygynnyng of the 7 hows is nadir of the Assendent ... .

und so bis $\S 36,17$ stets is, während vorher in genau demselben zusammenhange $\S 36,2,-5,-7,-10$ wol steht. und so häufig.

5. Pfle gen. Gerade dieses verhältniss kann in den meisten fällen vom praesens allein gentigend ausgedruckt werden, zumal da der zusammenhang hier stets jeden zweifel beseitigt, - nur $\mathrm{da}$, wo es sich um eine ganz besondere hervorhebung des begriffs der widerholung handelt, treten die entsprechenden modalverba ein (meist wol).

T. Prioresse 49. As smale childer doon in her childhede.

Hertzberg 13,430 . '. . . so wie allerwegen

In solchem alter kleine kinder pflegen.'

und so ausserordentlich hänfig; vgl. hierzu kap. 3, 1 a.

2. Im nebensatz.

a) im temporalsatz

a) mit ar, or, er.

T. Ch. Y. 49. I wol doon a maystry er I go!

T. Persone $272,10-12$. suffre, Lord, that I may a while . . weepe, or I go ... to the derke lond.

Philom. 74. That she may seen me sones or I deye.

Ebenso Prol. Coke 35, 38; Pr. Ch. Y. 156; Troilus I, 1014. II, 214, 278. 1II, 891. V, 1801 u. so oft.

B) mit til.

Pr. Ch.Y.70. . . al this ground on which we ben ridynge Til that we comen to Caunterbury toun ...

Troil.III, 717. Youre wommen slepen alle, I undertake So that for hem the housmen myghte myne, And slepen wollen til the sonne shyne.

ib. III, 581. I an, til God me bettere mynde sende, At dulcarnon, ...

Boëth. 1468. al pe peoples pat phebus pe sonne may seen comyng from his outerest arysyng til he hideth his bemes vndir pe wawes.

Das erste und letzte beispiel zeigen recht deutlich, wie in til ursprünglich ein raumverhältniss zu grunde liegt, das erst auf die zeit ubertragen ist -- und so erklärt sich auch das praesens hier sehr gut in eigener funktion.

Ebenso Astrolabe II, $\S 7,12$; II, § 12, $1-\S 12,3-\S 12$, $24-\S 14,4-\S 23,2-\S 23,9-\S 27,3-\S 28,4-\S 38,12$; Boëthius 741 u. so oft. 
whan in der bedentung von til.

Astrolabe II, $\S 35,6$. Awaite wel thanne whan pat thi sterre fix is in the same altitude .....

Ebenso II, § 25, 21 u. öfter.

r) mit whan, when, whanne, whanne that - meist in der bedeutung von 'so bald als'.

'T. Reere 131. The more queynte knakkes that they make, The more wol I stele, whan I take.

'T. Clerk II, 159.

And eek whan I say ye, ye say not nay,

Neyther by word, ne frownyng countenaunce.

Swer this, and here swer I our alliance.

T. Pard. 338. Whan it is night, we wol this tresour carie...

'Troil. V, 992. That when I se that I nevere er sey, Thanne wol I werke...

ib. II, 1740. That wol ye bothe seyne, when ye ben oon.

Prol. 9 G. W. 101.

That schal I seyn, whanne that I see my tyme.

Ebenso T. Miller 384; Pr. Frere 27; 'T. Prioresse 82; Melibeus 189, 7; T. Doctour 71; T. Ch. Y. 94 u. so oft.

$\delta)$ as swyth as - ebenfalls in der bedeutung von 'so bald als'.

Troil.V, 1383. For was ther never herte yit so blithe

To have hys lyf, as I shal ben as swyth

As I you see. u. öfter.

$\varepsilon)$ mit whil, whiles, whils, whil that.

'T.Knight 437. For I moot weepe and weyle, whil that I lyve.

Pr. Ch.Y.183. Whil I lyve schal I it quite never.

(Cuckow and N. 140).

T. Ch. Y. 126. And schet the dore, whils we ben aboute

Our privetee, that no man us aspye,

Whiles we werken in this philosophie.

'T. Pard. 366. I schal ryf him thurgh the sydes tweye

Whils thou strogelest with him as in game.

Ebenso T. Knight 1557-60; Pr. Bathe 157; Melib. 190, 33 u. ö.

5) mit as fer as.

T. Frank 257. . . as fer as I have wit,

I wole ben his to whom that I am knyt. ö. öfter.

b) Im lokalsatz.

T. Somp. 512. I schal defame him everal wher I speke.

'T. Pard. 338. we wol this tresour carie

By oon assent, ther as us liketh best.

T. N. Pr. 185. This night I schal be murdrid ther I lye.

Astrolabe II, $\S 31,7$. but waite in which azymut pat thi sonne entreth at his arisyng.

Ebenso T. Pardoner 339; Astrolabe II, § 27, 5- $\$ 25,5$ u. so oft. 
c) Im relativsatz.

a) Der relativsatz vertritt ein adjectiv. - Hier bedarf das verb des relativsatzes meist noch einer ausdrticklich auf die zukunft weisenden zeitbestimmung.

Melib. 197, 21. he is so . . merciable, that he wil . . bringe us to the

blisse that never hath ende.

T. Nonne Pr. 303-6. Macrobius ...

Affermeth dremes, and saith that thay been

Warnyng of thinges that men after seen.

Vgl. dazu ib. 311. ... dremes ben som tyme

Warnyng of thinges that $\mathrm{schul}$ after falle. u. offer.

$\beta)$ Der relativsatz vertritt ein substantiv.

T. Sec. N. 78. Yet pray I you that reden that I write. U. so öfter.

$\gamma$ ) Der relativsatz ist zugleich bedingungsatz.

T. Kn. 1693. And he that is at meschief schal be take.

ib. 850 . . . anon he schal be deed,

That smyte th eny strook, that I may seen.

Pr. Monk 34. That schal he fynde that hire mysd oth or saith.

T. Pard. 333. And he that $h$ ath the cut, with herte blithe

Schal renne to the toun.

T. Schipman 138; T. Sec. Nonne 78 u. öfter.

d) Im bedingungssatz, aber nur, wenn die bedingung in ein temporalverhältniss eingekleidet ist.

T. Frank 264. Loke, what day that endelong Bryteyne

Ye remewe alle the rokkes, ston by stoon, ...

Pers. 287, 11. God wot, that what day ye ete therof, youre eyen schal open ...

u. öfter; vgl. oben a, $\gamma$.

Anmerkung 1. In allen diesen fällen ist der futurische sinn des praesens im nebensatze durch den hauptsatz, der meist einen futur oder einen imperativ enthält, deutlich angezeigt.

A nmerkung 2. Im gewöhnlichen bedingungssatze steht nicht das zeitverhältniss im vordergrund, sondern das verhältniss von müglichkeit und wirklichkeit - und es gilt hier nicht den begriff der zukunft, sondern den der ungewissheit zu betonen. Es ist eine verkennung des tatsächlichen verhältnisses, hier eine vertretung des futurums durch den conj. praes. anzunehmen, wie dies Brinkmann II, s. $685 \mathrm{~b}$. und vor und nach ihm andere tun, indem sie diese sätze den obigen anreihen.

Selbst in bedingungssätzen, in denen die handlung unzweifelhaft nur als zukünftig aufgefasst werden kann, tritt dies zu tage.

Pr. Miller 31. And therefore if that I mys-speke or seye

- Wyte it the ale of Southwerk, I you preye.

(Er weiss es gar nicht, ob er es tun wird). - Dies drückt der conj. aus; stände das futur, so würde dadurch ausgedrückt, dass er es schon ganz bestimmt wlisste. Also futur und conj. praes. ergeben einen verschiedenen sinn. Stände dagegen der indic. praesentis, so wäre die annahme, 
dass hier eine vertretung des futurs vorliege, noch eher berechtigt, obgleich auch der indic. praes. dem gedanken eine andere färbung gibt als das futur - nämlich die der grösseren selbstgewissheit. Der indic. praes. setzt eine handlung schon als wirklich, während das futurum sie als zukünftig und damit nur erst als vorgestellt bezeichnet. - Aehnliches ist zum concessivsatz zu bemerken.

III. Hin und wider findet sich das praesens anch da, wo die streng-logische ausdrucksweise das futurum II verlangen wlirde. Da von einem gebrauch des futurum II bei Chaucer noch nicht die rede sein kann (vgl. fut. II), so gelangt entweder der begriff der vollendung im futurum gar nicht zum ausdruck, so dass fut. I (Koch II, § 47) und praesens sich in die funktionen desselben teilen - oder er findet seinen ausdruck im perfect und der begriff der zukunft wird anderweitig, ausserhalb des tempus bezeichnet. Vgl. Perf. kap. 2, § 2 .

Das praesens findet sich so:

Boëthius 3405. pan at arst skal he faylen of mede whan he forletip to ben good.

Original IV, Prose 3, 19. tum suo praemio carebit, cum probus esse desierit.

T. Melib. 196, 14. And I pray yow, that ye wol forbere now to do vengeaunce ... (18) that ye have noon cause to repente yow of thing that ye doon.

T. Nonne Pr.122. 'whan we fle fro thise beemes, For Goddis love, as tak som laxatyf.

Troilus IV, 1247. I shal wele bryngen it aboute

To com ayein, soon efter that I go. u. so oft.

Diese erscheinung ist aber eigentlich weniger vom grammatischen, als vielmehr vom psychologischen standpunkte aus bemerkenswert. Sie zeigt, dass die damalige denkweise die zeitsphäre der zukunft noch nicht so scharf von der gegenwart trennte, als der schriftgebrauch späterer, im logischen denken besser geschulter generationen. Dasselbe gilt von all den sub \$ 2 angefthrten fällen, daher denn auch noch heute dieser gebrauch, besonders fur die sub II angefuhrten fälle in der volks-. und gewöhnlichen umgangssprache nichts seltenes ist.

Es muss also betont werden, dass bei Chaucer von einer vertretung des futurs durch das praesens, wie dies im Altenglischen der fall war, nicht mehr die rede sein kann; da, wo es gilt, den begriff des zukunftigen als wesentlich zu bezeichnen, zeigt Chancer stets futurische (umschreibende) zeitformen; da, wo wir jedoch das praesens finden, wälirend die streng-logische 
denkweise das futur verlangen würde, ist dies nicht fur die sprache, d. i. grammatisch, sondern fur die anschaungsweise, d. h. psychologisch bemerkenswert. So lässt sich auch für die form ben bei Chaucer keine besondere, futurische bedeutung mehr nachweisen, welche M. II, 76 für beom im Angelsächsischen belegt.

Kap. 3.

Das praesens kein tempus, sondern nur subjekttragende verbalform.

Dasjenige, was eine verbalform zum tempus maekt, ist die eigenschaft, die zeitsphäre zu bestimmen, in welcher ein verbalbegriff verwirklicht gedacht wird.

Nur da, wo diese bestimmung eime absolute ist, ist das tempus ein echtes tempus.

$\mathrm{Da}$, wo diese bestimmung nur relativ, d. h. mit bezug auf die zeitsphäre einer anderen handlung geschieht, sinkt das tempus zum stellvertretenden oder besser zum tempus relativum herab.

Verliert die form des tempus jede zeitbestimmende funktion, gilt also das von ihr ausgesagte nicht fur eine bestimmte zeitsphäre, sondern gleichmässig für alle, - bezw. negiert gleichmässig für keine, so hat die verbalform aufgehört, tempus zu sein. Sie ist dann nur noch subjekttragende verbalform.

Auf dieser stufe finden wir das praesens

1. da, wo es tempus des prädikats ist, welches von seinem subjekt etwas in dessen wesensbeschaffenheit liegendes aussagt.

a) Es dient dazu, tätigkeiten auszusprechen, die aus der wesensbeschaffenlieit des subjekts hervorgehen und an keine zeitsphäre gebunden sind.

a) Das praesens steht ohne zeitbestimmungen. Man kann es hier meist mit 'pflegen' umschreiben.

Boëthius 1433. Also musyk makep masiciens . and fysik makep phisiciens, and rhetorik rhetoriens ...

T. Frank 222. That languisshith as fuyr doth in helle

ib. 227 .

... at daunces

Ther yong folk kepen here observaunces.

T. Squyer 196. They murmured, as doth a swarm of been.

T. Persone 329,4 . for it (this vertu) enhaunsith and enforceth the soule, right as accidie abateth it and makith it feble.

Und so unzählige male. 
B) Es steht ein adverb der zeit dabei, dàs die widerkehr der handlung ausdrucklich bezeichnet.

Astrolabe II, $\S 28,14$. thise signes arisen euer-mo by-twyxe the verrey este $\&$ the verrey sowth in owre orisonte.

T. Frank 51. For in this worlde certeyn no wight ther nys, That he ne doth or saith som tyme amys.

ib. 54. Wyn, wo, or chaungynge of complexioun, Causeth ful often to don amys...

T. Persone 339, 30. a man somtyme forgetith by the morwe, what he dide at eve.

und so ganz gewöhnlich.

b) Es dient dazn, die angehörigkeit von eigenschaften auszusprechen, die in der wesensbeschaffenheit des subjekts begrtundet und in ihrer existenz an keine bestimmte zeitsphäre gebunden sind.

T. Kn. 177. That Emelie, that fairer was to seene, Than is the lilie on hire stalkes grene.

T. Frank 199. That freisscher was and jolyer of array As to my dome, than is the monthe of May.

T. Persone 341,2 . these two synnes ben so neih cosyns, that ofte tyme thay wol not departe.

ib. 329,1 . This vertu is so mighty and so rigorous, that ...

Boëthius 1432. in whom pat swiftenesse is(,) Sothe it is pat he is sw yfte. u. s. w.

c) Es dient behufs klassifikation des subjekts dazu, dasselbe unter begriffe, welche seine wesensbeschaffenheit näher erläutern und in ihrer geltung an keine zeitsphäre gebunden sind, za subsumieren. Hier sinkt das existentialverbum zur copula herab.

T. Frank 39. Love is a thing as any spirit fre.

T. Persone 330, 14. Avarice ... is a likerousnes in hert to have erthely thinges.

ib. 338, 27. Glotenye is unresonable and desordeyned coveytise ... u.s.w.

2. In allgemeinen erfahrungssätzen und sinnspruchen.

T. Kn. 681. Selde is the Fryday al the wyke i-like

ib. 954. A man moot ben a fool other yong or olde.

ib. 1591. Men may the eelde at-renne, but nat atrede.

ib. 663. For soth is seyde, goon ful many yeeres,

That feld hath eyen, and the woode hath eeres. u.s. w.

3. Zum ausdruck allgemeiner verhältnisse.

T. Lawe 932. Now was this child as lik unto Custaunce,

As possible is a creaturo to be.

Astrolabe I, $\S 16,10$. 5 of thise degrees maken a Milewey, \& 3 Milewey maken an howre... 
Ebenso in dem formelhaften as who seip = gleichsam, als ob (Boëthius 1977 u. s. w.), und in dem ausdruck ähnlicher art that is Io sayn (M. 140,6. 171,25 u. s. w.) und so sehr oft.

4. In der berichterstattung. Auch hier ist das vom praesens ansgesagte an keine zeitsphäre gebunden, bezw. keiner bestimmten zeitsphäre zugewiesen.

a) Bei quellenangaben von citaten.

'T.Sec.N.120. 'This mayden bright Cecilie, as hir lyf saith, Was comen of Romayns and of noble kynde.

Zahlreiche beispiele hierzu sub kap. 1, § 2, 3 anmerkung.

b) Bei inhaltsangaben.

Pr. Bathe 650. And thanne wold he upon his book seeke

That ilke proverbe of Ecclesiaste,

Wher he comaundith and forbedith faste; ...

Pr. Clerk 41. I say that he first with heigh stile enditith

[Er he the body of his tale writith]

A probeme, in the which descrivith he

Piemounde, and of Saluces the contre,

And spekith of Appenyne ...

T. Persone 272, 26. The cause why that Job calleth, helle the lond of derknes, understondith, that he clepith it lond or eorthe, for it is stable.

Parl. of F. 36. First telle th hyt, (sc. 29 This booke) whan Scipion was come lnto Aufryke, how he mette Massynysse, ...

ib. 39. Than telleth he hir speche and al the blysse That was betwixt hem ...

Ebenso Prol. Melib. 26-27; T. Sec. Nonne 113, 271; T. Monk 137, 728-30; Boëthius 1531-32 u. so öfter.

Interessant ist, dass das praesens hier mit dem praeteritum wechselt.

Boëthius 1976. For whiche ping catullus clepid a consul of Rome pat hyzt nonius pustum . or boch as who seip he clepip hym a congregacioun of nices in his brest as a postum is ful of corrupcioun. Vgl. weitere beispiele sub kap. $1, \S 2$, anmerkung zu 3.

\section{HUSUM.}

A. Graef.

Anmerkung. Ad s. 40, z. 4 meiner abhandlung über das perfektum bei Chaucer ist zu bemerken, dass bei Fiedler und Sachs II, s. 80, ausg. 1861 allerdings ein vereinzeltes beispiel aus Ch. fïr den betreffenden perfektgebranch angefiihrt ist ... ein beispiel, das in seiner vereinzeltheit jedoch als hinreichender beleg fiir den betreffenden gebrauch des pert. iu Me. schwerlich anzusehen sein dürfte. 